\title{
Entre o previsível e o contingente: etnografia do processo de decisão sobre uma política de ação afirmativa ${ }^{1}$
}

\author{
Ciméa Barbato Bevilaqua
}

Professora do Departamento de Antropologia - UFPR

\begin{abstract}
RESUMO: Este artigo apresenta uma etnografia do processo de decisão sobre o estabelecimento de ações afirmativas na Universidade Federal do Paraná, enfocando particularmente as sessões do Conselho Universitário que culminaram com a aprovação de um Plano de Metas de Inclusão Racial e Social na instituição. Ao situar empiricamente o tema das cotas nas universidades, torna-se possível incorporar novos elementos à reflexão sobre as políticas públicas de ação afirmativa, bem como identificar princípios subjacentes à dinâmica da formulação de normas institucionais numa instância específica do setor público. A análise do material etnográfico sugere uma aproximação com a lógica do sacrifício, tal como descrita por Marcel Mauss.
\end{abstract}

PALAVRAS-CHAVE: políticas públicas, sistema de cotas, universidade.

O estabelecimento das chamadas políticas de ação afirmativa evidencia a complexidade da articulação lógica e política entre o princípio da igualdade, atributo básico da cidadania no ordenamento jurídico dos Estados democráticos contemporâneos, e a consideração das diferenças entre grupos e/ou segmentos sociais específicos, seja em termos de eqüidade de tratamento ou pela afirmação da alteridade étnica ou cultural como um valor. Por esse aspecto, a implantação de cotas para o ingresso de 
estudantes negros, indígenas ou oriundos de outros segmentos sociais específicos nas instituições públicas de ensino superior constitui um caso exemplar, uma vez que traz à tona diferentes dimensões do equacionamento entre igualdade e diferença, direitos individuais e coletivos, ciência e política.

É a implantação de cotas para negros que, em particular, tem suscitado um acalorado debate dentro e fora da academia, sobretudo a partir da promulgação da primeira lei sobre reserva de vagas nas universidades estaduais do Rio de Janeiro, em 2001. O surgimento de outras iniciativas similares - como a da Universidade do Estado da Bahia, em 2002, seguida mais tarde pela Universidade Estadual de Mato Grosso do Sul fez com que em poucos anos uma produção acadêmica relativamente vasta se acumulasse sobre o tema. A questão das cotas nas universidades foi, por exemplo, o tema central do dossiê "O negro no Brasil", publicado em 2004 pela revista Estudos Avançados. ${ }^{2}$ Ainda mais recentemente, a revista Horizontes Antropológicos promoveu um amplo debate acerca do vestibular da Universidade de Brasília, primeira instituição federal a implantar um sistema de cotas no Brasil, no segundo semestre de 2004 . $^{3}$

Diferentemente das contribuiçôes acima referidas, este artigo não toma como objeto os fundamentos ou as possíveis implicações mais gerais e duradouras da reserva de vagas nas universidades, tampouco o papel dos cientistas sociais nesses processos. $\mathrm{O}$ foco aqui é o próprio processo de decisão sobre a existência e o conteúdo de tal política num contexto específico. Trata-se de oferecer uma etnografia da discussão sobre o estabelecimento de cotas para o ingresso de alunos na Universidade Federal do Paraná e, em particular, das três sessões do Conselho Universitário que culminaram com a aprovação do Plano de Metas de Inclusão Racial e Social na instituição.

Ao situar empiricamente o tema das cotas nas universidades, talvez se torne possível identificar e incorporar à reflexão sobre essa e outras 
políticas sociais de ação afirmativa elementos cuja importância tende a passar despercebida quando a análise se mantém mais distante das experiências concretas e de contextos específicos. Em outro registro, a abordagem etnográfica da deliberação sobre o estabelecimento de cotas também pode contribuir para a compreensão da dinâmica da formulação de normas institucionais numa instância específica do setor público.

\section{O Plano de Metas}

No início de agosto de 2002, quatro meses depois de tomar posse para um mandado de quatro anos, o reitor da Universidade Federal do Paraná constituiu uma comissão encarregada de definir um "plano de metas de inclusão social para a UFPR". Ainda que as atribuições da comissão fossem relativamente imprecisas, sua composição não deixava dúvida sobre o horizonte visado. Dos quatro membros designados para compor a comissão, três eram negros, numa instituição em que a presença de negros, sobretudo no corpo docente, é historicamente muito reduzida. ${ }^{4}$

A constituição da comissão passou quase despercebida naquele momento, a despeito de diversas iniciativas para estimular o debate acerca de políticas afirmativas na universidade. No entanto, quando a proposta de implantação de cotas veio à luz, um ano e meio mais tarde, a percepção predominante era que o projeto havia sido gestado sem a participação da assim chamada comunidade universitária. Nessas circunstâncias, o Plano de Metas de Inclusão Racial e Social não era comparado às iniciativas similares já em curso em diversas universidades, mas a outro projeto polêmico no âmbito da própria UFPR: o Processo de Ocupação de Vagas Remanescentes (Provar), ${ }^{5}$ aprovado no primeiro ano de gestão sob forte protesto dos estudantes. Nos dois casos, uma interpretação corrente (não necessariamente "falsa" ou "verdadeira") era que a 
impetuosidade da administração sacrificava o amadurecimento democrático de seus projetos.

A proposta da comissão reproduzia quase integralmente, em estrutura e conteúdo, a que havia sido apresentada pelos antropólogos José Jorge de Carvalho e Rita Laura Segato à Universidade de Brasília (Carvalho e Segato, 2002). ${ }^{6}$ Propunha-se a reserva de $20 \%$ das vagas do vestibular da UFPR, por um período de dez anos, para estudantes negros; outros $20 \%$ para estudantes oriundos da escola pública, por igual período; e a disponibilização de vagas para índios, sem número ou prazo definidos. Convém apontar, porém, algumas das diferenças entre as duas proposições. O modelo da UnB não previa cotas para estudantes da rede pública, mas uma "ação afirmativa de cunho social nas escolas públicas de ensino médio do Distrito Federal". Mais importante, enquanto a proposta dos antropólogos de Brasília considerava unicamente a autodeclaração como critério para a inscrição dos candidatos negros, ${ }^{7}$ a proposta da UFPR acrescentava a possibilidade de sançóes àqueles que fizessem "declaração falsa ou fraudulenta". Aproximava-se assim da norma adotada pela Universidade Estadual do Rio de Janeiro (Uerj), que condicionava a autoclassificação racial dos candidatos às "penas da lei". 8

Outras diferenças deixam transparecer que os índios não eram objeto de atenção específica da comissão designada pela reitoria da UFPR, e que talvez tenham sido incluídos no Plano de Metas unicamente porque já figuravam na proposta apresentada à UnB. Todas as referências aos estudantes indígenas no corpo do documento reproduziam de modo quase literal o modelo brasiliense. Ao mesmo tempo, o texto introdutório redigido pela comissão da UFPR não fazia qualquer menção aos índios.

Embora o texto já estivesse concluído há cerca de um ano, a proposta da comissão só foi recebida oficialmente pela reitoria da UFPR no dia 30 de março de 2004. Nesse momento, a apresentação do Plano de Metas ao Conselho Universitário era justificada publicamente pela ne- 
cessidade de definir as normas do próximo vestibular ainda no primeiro semestre, para que o concurso pudesse ter início em novembro. Mais tarde, o reitor revelaria em entrevista coletiva (à qual estive presente) que houvera a intenção de anunciar a política de cotas no dia 13 de maio, cronograma que por certo levava em consideração tanto o apelo simbólico que a data possivelmente teria para a opinião pública quanto a probabilidade de reunir a maioria suficiente para aprovar a proposta e para sustentar sua implantação.

Já sob a forma de processo, o texto elaborado pela comissão foi encaminhado ao diretor do Setor de Ciências Humanas, Letras e Artes, designado para relatar a proposta ao Conselho Universitário (Coun). ${ }^{9}$ Órgão deliberativo máximo da UFPR, o Conselho Universitário é constituído pela agregação de dois outros conselhos superiores da instituição: o Conselho de Ensino, Pesquisa e Extensão (Cepe) e o Conselho de Planejamento e Administração (Coplad). Além do reitor e da vice-reitora, respectivamente presidente e vice-presidente, o Coun tem 49 membros e igual número de suplentes. Dele fazem parte os diretores dos dez setores acadêmicos da Universidade; o diretor da Escola Técnica da UFPR, que também tem status de setor acadêmico; um professor representante de cada setor e da Escola Técnica; um representante dos coordenadores de cursos de graduação; um representante dos coordenadores de cursos de pós-graduação; dois representantes de cada classe docente do ensino superior (auxiliar, assistente, adjunto e titular) e do ensino técnico; seis representantes discentes de graduação; um representante discente de pósgraduação; quatro representantes dos servidores técnico-administrativos; e quatro representantes da comunidade (dois de órgãos patronais e dois indicados por entidades de trabalhadores).

A composição do Coun é suficiente para indicar diferenciações internas que independem de atributos pessoais dos conselheiros. Apesar do vínculo genérico que aproxima os professores entre si e ao mesmo 
tempo os distingue dos servidores técnico-administrativos e dos estudantes, os representantes do corpo docente são eleitos de forma individualizada e não se reúnem senão nas próprias sessões dos conselhos de que participam. Assim, não chegam a constituir um grupo e não atuam coletivamente nos debates e nas votaçôes. $\mathrm{O}$ mesmo se aplica, de modo ainda mais claro, aos representantes da comunidade. A atuação dos representantes discentes, por sua vez, reflete divisóes internas do movimento estudantil. Os servidores atuam em bloco e se auto-intitulam a "bancada dos técnicos", mas seu número é insuficiente para definir as votações. Desse modo, os diretores de setores acadêmicos representam o segmento politicamente mais forte do Conselho Universitário, ainda que não constituam um grupo homogêneo.

Essa breve digressão evidencia que a escolha de um dos diretores como relator do Plano de Metas procurava assegurar alguma previsibilidade à apreciação da proposta e, indiretamente, favorecer a aprovação do sistema de cotas. Além do peso relativo de sua posição institucional, a área acadêmica de origem e outros atributos pessoais e políticos do diretor do setor de Ciências Humanas compunham provavelmente o perfil mais adequado, dentre os membros do Coun, para o encaminhamento bem-sucedido de uma proposição sabidamente polêmica.

Uma das primeiras iniciativas do relator foi enviar cópia da proposta aos demais diretores. Não houve todavia nenhuma manifestação sobre uma matéria cuja relevância, de acordo com as práticas costumeiras, teria suscitado uma ou mais reuniōes do chamado Fórum de Diretores. Até o final das votações do Plano de Metas, aliás, pesaria sobre o relator do processo um distanciamento quase religioso que evidenciava o desconforto mais ou menos generalizado entre os membros do Conselho Universitário em relação às políticas afirmativas.

Três semanas depois de receber o processo, o relator concluiu seu parecer, que mantinha o cerne da proposição original: reserva de $20 \%$ 
das vagas do vestibular para negros; outros $20 \%$ para estudantes oriundos de escolas públicas; e criação de vagas suplementares para estudantes indígenas. Embora tenha introduzido algumas alterações (que serão comentadas mais adiante), o parecer só se opunha diretamente a dois aspectos da proposta da comissão, justamente aqueles que - além da reserva de vagas para estudantes do ensino público - a diferenciavam do modelo da Universidade de Brasília: o estabelecimento de sanções aos candidatos que cometessem fraude ${ }^{10}$ e a participação obrigatória dos cotistas em reuniōes de avaliação do programa.

\section{A primeira sessão: entre o excepcional e o regimental}

A primeira sessão do Conselho Universitário da UFPR para a deliberação sobre o Plano de Metas de Inclusão Racial e Social foi convocada para as $8 \mathrm{~h} 30 \mathrm{~min}$ do dia 6 de maio de 2004, uma quinta-feira. Noticiada pela imprensa, a inclusão da proposta de implantação de cotas na ordem do dia surpreendeu parte da comunidade universitária e pôde ser interpretada como mais um gesto precipitado da reitoria. A chegada da matéria ao Coun, no entanto, era o resultado de uma trajetória de quase dois anos, possibilitada em parte pelo quadro político no interior da própria UFPR e, num plano mais abrangente, pelo movimento que vinha se delineando na administração pública federal pelo menos desde 1996, quando o Programa Nacional de Direitos Humanos propôs "açóes afirmativas para o acesso dos negros aos cursos profissionalizantes, às universidades e às áreas de tecnologia de ponta" (Maggie e Fry, 2004, p. 71; Maio e Santos, 2005a). ${ }^{11}$ O próprio tempo decorrido entre a finalização da proposta do Plano de Metas e sua apresentação ao Conselho Universitário indica o cuidado com que se procurou preparar o terrreno e minimizar contingências que pudessem dar à proposição um 
curso diferente do esperado. Ainda assim, a tramitação no Coun mostraria que as circunstâncias contingentes são, de fato, necessárias (cf. Sahlins, 1990, p. 144).

$\mathrm{Na}$ noite anterior à sessão do Conselho Universitário, entidades do movimento negro organizaram uma vigília no pátio em frente ao prédio da Reitoria. Poucos militantes enfrentaram a fria madrugada do outono curitibano, mas sua presença foi suficiente para alimentar uma atmosfera de tensão que permaneceria na manhã seguinte. Um esquema de segurança especial foi providenciado para que apenas os membros do Coun tivessem acesso ao prédio onde são realizadas as reuniões do Conselho. Essa medida excepcional possivelmente se devia à experiência recente da ruidosa manifestação dos estudantes para impedir a aprovação do Processo de Ocupação de Vagas Remanescentes (Provar), tema comparativamente bem menos polêmico que a política de cotas. Dessa vez, porém, não houve nenhuma mobilização dos estudantes, contra ou a favor da proposta. Professores e servidores técnico-administrativos também não se manifestaram, seja informalmente ou por meio dos respectivos sindicatos. A entrada dos conselheiros foi acompanhada somente por jornalistas e militantes do movimento negro que distribuíam silenciosamente um manifesto em defesa das cotas.

A sala do Conselho fica no segundo andar do prédio da Reitoria, uma construção de estilo modernista do final da década de 1950. A ambientação solene contrasta com as linhas retas da arquitetura, mas compõe um cenário adequado às condutas ritualizadas que prevalecem nas reuniōes. Numa das extremidades do amplo salão retangular fica a mesa da presidência, de madeira maciça entalhada. A parte central, cerca de 50 centímetros mais alta, é ocupada pelo reitor, na qualidade de presidente do Conselho Universitário. O lugar à esquerda é reservado à vicereitora, enquanto à direita se senta o secretário. No extremo oposto à mesa da presidência há uma mesa menor, do mesmo material, habitual- 
mente ocupada pelos servidores técnico-administrativos. Entre esses dois pólos ficam duas longas bancadas em forma de elipse com microfones dispostos a intervalos regulares. As pesadas poltronas vermelhas que circundam as bancadas não são suficientes para acomodar todos os conselheiros. Os últimos a chegar ocupam cadeiras comuns de escritório alinhadas junto às paredes.

Naquela manhã, os conselheiros se limitavam a cumprimentos em voz baixa enquanto aguardavam os demais. A sociabilidade que costuma anteceder as reunióes - momento importante para trocar informações, tratar informalmente de questões administrativas, tecer e consolidar redes de relaçóes - tinha dado lugar a uma atmosfera anormalmente grave que permaneceria até o final da sessão. Embora discreta, era visível a evitação do relator. Por volta das $8 \mathrm{~h} 30 \mathrm{~min}$, a porta dupla que dá acesso à Sala do Conselho foi trancada à chave. A essa altura, todos os lugares já tinham sido ocupados por 53 membros do Coun. Além do reitor e da vice-reitora, estavam presentes 40 conselheiros titulares (nove diretores de setor) e 11 suplentes (quatro vice-diretores). ${ }^{12}$ Compareceram também os seis pró-reitores. Em particular, chamava atenção a presença do conselheiro $\mathrm{A}(\mathrm{CD}),{ }^{13}$ jurista respeitado na área de direitos humanos, que só participava das reuniões em momentos excepcionais.

Mesmo os gestos mais corriqueiros assumiam uma formalidade menos evidente em outras ocasióes. Foi em tom solene que o reitor, como presidente do Conselho, deu início à sessão. Imediatamente depois de aprovada a ata da reunião anterior, um dos conselheiros levantou questão de ordem quanto à presença de pessoas estranhas ao Coun. Referiase de modo específico aos integrantes da comissão responsável pela proposta do Plano de Metas de Inclusão Racial e Social, que haviam ocupado estrategicamente as cadeiras atrás do relator do processo. Após deliberação formal, foi autorizada a permanência da comissão e a entrada de um representante de cada entidade do movimento negro e dos 
órgãos de imprensa presentes. Também invocando norma regimental, outro conselheiro propôs que, no momento da votação, permanecessem na sala apenas os membros do Conselho. A proposta foi aprovada por 25 votos a 8 .

Faço parênteses aqui para indicar as condições em que acompanhei a tramitação do Plano de Metas de Inclusão Racial e Social. Além de professora do Departamento de Antropologia, assumi no final de 2003 a função de vice-diretora do Setor de Ciências Humanas, Letras e Artes da UFPR. Nessa condição, tive acesso à elaboração do parecer sobre a proposta e à parte dos movimentos que antecederam seu exame pelo Conselho Universitário - do qual também faço parte na qualidade de suplente. A elaboração deste artigo só se tornou possível, no entanto, a partir da decisão do plenário do Coun de permitir que pessoas estranhas ao Conselho e à própria universidade presenciassem a deliberação. Acredito que o caráter relativamente público das sessões me autoriza a discuti-las publicamente. Também optei por não apresentar informações às quais só tive acesso em virtude da posição que atualmente ocupo. Não seria possível desconsiderar, porém, que foi a experiência anterior de participação no Conselho Universitário que me permitiu perceber a excepcionalidade das sessōes que deliberaram sobre as políticas afirmativas, em contraste com as condutas habituais dos conselheiros.

Um exemplo disso é a própria invocação do regimento, ao qual os conselheiros raramente fazem referência direta. Mas vale perguntar: que regimento? O regimento do Conselho Universitário data de 1952, quando ainda vigorava o regime de cátedras no ensino superior. O Regimento Geral da UFPR, mais recente, estabelece normas sobre as sessōes dos Conselhos superiores (artigos 9oa 21ํㅡ), mas não faz nenhuma referência aos pontos aludidos pelos conselheiros no início da sessão. Dispõe apenas que a discussão e a votação dos assuntos em pauta sejam feitas "de acordo com a praxe seguida na condução dos trabalhos dos cole- 
giados" (art. 15), o que nos remete aos regimentos do Conselho de Ensino, Pesquisa e Extensão (Cepe) e do Conselho de Planejamento e Administração (Coplad).

Neles se encontram, até certo ponto, as normas invocadas pelos conselheiros, embora nada autorize considerar que o Conselho Universitário, por ser constituído pela reunião dos dois outros conselhos, também deva pautar seus trabalhos pela soma de seus respectivos regimentos. Esses dois documentos prevêem que a qualquer momento poderão ser levantadas questóes de ordem. ${ }^{14}$ Da mesma forma, ambos facultam ao plenário autorizar a participação de "pessoas cujos depoimentos possam esclarecer assuntos de qualquer natureza”, embora estabeleçam explicitamente que tais pessoas não podem "tomar parte em debates e nem presenciar as discussões" ${ }^{15}$ No entanto, a autorização para que jornalistas e representantes do movimento negro acompanhassem a sessão também não era propriamente anti-regimental, já que, à luz do artigo do Regimento Geral da UFPR citado acima, estar-se-ia simplesmente procedendo "de acordo com a praxe".

Essa circularidade das normas regimentais possibilita que elas não sejam usadas apenas como normas para a ação, mas sobretudo como argumentos para impor limites a outros argumentos, cuja eficácia reside justamente no fato de que ninguém (ou quase ninguém) pode estar seguro da existência ou da aplicabilidade da norma invocada por outrem em certo momento. A possibilidade de apelar a normas oriundas de um ou outro regimento permanece sempre aberta, assim como as muitas possibilidades de combinação entre elas conforme as circunstâncias. De acordo com esse aspecto, as seguidas menções ao(s) regimento(s) dão contornos objetivos à sensação de excepcionalidade que envolvia todos os presentes: a discussão do Plano de Metas constituía de fato um momento crucial de negociação de limites que, não sendo apenas nem primeiramente regimentais, ao término da dicussão viriam a ser consolidados como norma. ${ }^{16}$ 
Resolvidos os primeiros impasses, passou-se à ordem do dia. O presidente fez um breve discurso em tom favorável ao Plano de Metas, mas falava em voz mais baixa e de modo menos fluente que o habitual. Apresentou em seguida a metodologia dos trabalhos, que seguiria (poder-seia dizer, conforme o regimento) a praxe das demais sessões: após a leitura do parecer pelo relator, a proposta seria discutida e votada ponto a ponto. Ao concluir, o presidente lembrou que 10 de junho era a datalimite para a divulgação do edital do próximo vestibular. Era a deixa para que o relator pedisse regime de urgência na apreciação do Plano de Metas, em mais uma tentativa de assegurar a maior previsibilidade possível num contexto particularmente sensível às contingências.

$\mathrm{O}$ conselheiro $\mathrm{B}(\mathrm{CP})$, acostumado a utilizar normas regimentais e legais como estratégia permanente de atuação nos debates, reagiu de pronto. Argumentando que o regimento não admitia regime de urgência naquela matéria, ensaiou um pedido de vista do processo. Também aqui convém assinalar que o regimento do Coun nem sequer menciona o regime de urgência. Essa possibilidade é prevista pelos três outros regimentos, mas sem menção à natureza da matéria apreciada. ${ }^{17} \mathrm{O}$ Regimento Geral da UFPR permite inclusive que o presidente atribua urgência a determinado assunto da pauta por iniciativa própria sem necessidade de consulta ao plenário - o que, no entanto, contraria a praxe.

Seja como for, regimentalmente (isto é, de acordo com três dos quatro regimentos disponíveis), a urgência impede a concessão de vista do processo, recurso que permite adiar a discussão por pelo menos duas sessôes. Era isso o que a manobra do relator pretendia evitar e que o conselheiro $\mathrm{B}(\mathrm{CP})$, em resposta, ameaçava fazer. $\mathrm{O}$ conselheiro $\mathrm{A}(\mathrm{CD})$ se valeu de sua autoridade de jurista para neutralizar o argumento do colega engenheiro. De acordo com ele, não havia norma regimental específica impedindo o regime de urgência, podendo o Conselho Universitário decidir em matéria omissa. Ninguém ousou contestar o argumen- 
to - tecnicamente correto, à luz dos regimentos; e politicamente eficaz, dadas as credenciais do enunciante -, mas a medida foi aprovada com o voto contrário de oito conselheiros.

$\mathrm{O}$ relator do processo fez a leitura de seu parecer, do qual todos os presentes haviam recebido cópias. A exemplo do reitor, falava em voz baixa e insegura, mas venceu sem interrupção as 14 páginas de comentários minuciosos à proposta do Plano de Metas de Inclusão Racial e Social. Em rigoroso silêncio e com expressão grave, os conselheiros acompanharam a leitura. Como já foi mencionado, o parecer mantinha o cerne do projeto original, preocupando-se antes em justificar e especificar as políticas a serem adotadas. Ao final, o presidente parabenizou efusivamente o relator, de um modo que sugeria uma completa anuência da administração ao conteúdo do parecer.

A sessão havia chegado a um momento crucial. Conforme o encaminhamento previsto, era hora de decidir, antes de qualquer consideração sobre o conteúdo do projeto, se a Universidade Federal do Paraná iria ou não adotar políticas afirmativas. A presidência estabeleceu que, antes da votação, haveria três manifestações a favor e três contra a proposição. Contrariando o previsto, o debate se estendeu por mais duas horas, com intervenções de 18 conselheiros - o triplo do que havia sido convencionado. Se a limitação do uso da palavra, naquelas circunstâncias, certamente seria percebida como um cerceamento indevido, também é possível sugerir que o prolongamento do debate permitia à presidência uma avaliação mais precisa das tendências do plenário, bem como do momento adequado para colocar a matéria em votação com alguma segurança acerca do resultado.

Seria impossível reproduzir aqui as intervenções e os argumentos favoráveis e contrários às políticas afirmativas. Alguns aspectos, porém, merecem destaque. Em primeiro lugar, naquele contexto específico, o campo semântico da expressão "políticas afirmativas" se restringia 
claramente à adoção de cotas para estudantes negros no vestibular. Como a conduta dos conselheiros deixava entrever, essa associação situava imediatamente o debate num terreno minado de implicações de ordem moral, que a presença dos membros da comissão responsável pelo Plano de Metas e dos representantes do movimento negro só contribuía para acentuar. Mesmo os conselheiros mais experientes se expressavam como neófitos gaguejantes e inseguros, buscando sinais de aprovação no semblante dos colegas. Nessas circunstâncias, somente aqueles (poucos) que tinham um compromisso inequívoco com a política de cotas e os conselheiros que manifestavam posiçóes coletivas (mesmo que contra a proposta) não se deixavam afetar no mesmo grau pela atmosfera opressiva que colocava os atributos morais dos conselheiros, tanto ou mais que suas posições políticas, sob suspeição.

A apresentação inicial do reitor sobre o longo trabalho da comissão responsável pelo Plano de Metas, de um lado, e a aprovação do regime de urgência, de outro, haviam esvaziado o argumento habitualmente utilizado para manifestar discordância de forma indireta: a necessidade de um tempo maior de discussão da proposta antes de qualquer deliberação. Desse modo, a tensão exacerbada entre as dimensões da moralidade e da política, que incidia individualizadamente sobre cada um dos conselheiros, traduzia-se na preferência por argumentos de caráter "técnico", nos quais a oposição às políticas afirmativas aparecia de forma oblíqua e alusiva. ${ }^{18}$ Como tem ocorrido em outros contextos, questionavam-se a possível inconstitucionalidade das cotas (perante o princípio igualitário que fundamenta o ordenamento jurídico brasileiro) e as implicaçóes práticas do sistema, tanto em termos orçamentários quanto em relação ao desempenho acadêmico dos cotistas.

A etnografia não pode determinar, em termos causais, as "verdadeiras" motivaçôes dos conselheiros, seja no que diz respeito à decisão de se manifestar ou não, seja no que se refere ao significado "último" de suas 
intervenções. É possível encontrar em suas açōes, porém, algumas condições de inteligibilidade da dinâmica estabelecida naquele contexto. Minha sugestão é que o desenrolar do debate estabeleceu como resultado não-intencional do encadeamento das falas dos conselheiros uma polarização que, ignorando inteiramente os estudantes indígenas, situava negros e estudantes de escola pública em campos opostos. Os conselheiros que, por diferentes razões, resistiam ao estabelecimento de cotas para estudantes negros, manifestavam indiretamente sua posição privilegiando "ações afirmativas voltadas à escola pública". Inversamente, aqueles que apoiavam a reserva de vagas para estudantes negros tendiam a desconsiderar a questão da escola pública, ainda que não tivessem restrições a esse aspecto da proposta. Cabe assinalar que o parecer do relator havia demonstrado que a UFPR já contava com mais de $20 \%$ de alunos oriundos do ensino público, o que tornava praticamente inócua a proposta de cotas para esse segmento, exceto nos cursos de maior concorrência. Desse modo, a polarização entre cotas para negros e cotas para escola pública não era uma dualidade simples, mas uma oposição hierárquica, no sentido de Dumont (1992). A reserva de vagas para a escola pública era, até certo ponto, o inverso das cotas em geral.

Tem sido freqüientemente apontado em relação a diversas instâncias de deliberação coletiva que, mesmo quando as condiçôes formais de participação são idênticas para todos, critérios implícitos de hierarquização dos participantes não deixam de estar presentes. A dinâmica do Coun é marcada por princípios de diferenciação que se situam em dois planos dissociáveis apenas analiticamente. Já indiquei acima a importância no âmbito do Conselho das posições institucionais de seus membros na universidade - estudantes, técnicos ou docentes e, neste último segmento, aqueles que desempenham ou não funções de direção. $\mathrm{O}$ outro princípio de diferenciação, de certo modo secundário (por estar logicamente subordinado ao primeiro), diz respeito às reputaçôes 
construídas tanto fora do Conselho quanto pela avaliação da performance de cada um nos debates.

A conjugação das qualidades diferenciais pertinentes a essas duas ordens de consideração incide de modo decisivo sobre a legitimidade e o potencial de repercussão dos argumentos apresentados pelos conselheiros. Se os diretores de setores acadêmicos constituem o segmento mais influente do Conselho, nem todos os que integram esse conjunto desfrutam, como indivíduos, da mesma respeitabilidade. Ao mesmo tempo, um desempenho avaliado positivamente confere certo destaque a outros conselheiros, a despeito de uma posição institucional relativamente inferior. Em termos gerais, porém, prevalece uma escala que ordena, em seqüência, docentes, técnicos e estudantes. De modo aproximativo, é possível dizer que a "linha de frente" ${ }^{19}$ do Conselho Universitário é formada por três diretores de setor e, um degrau abaixo, três docentes. Numa região intermediária se situam: (a) os conselheiros que intervêm relativamente pouco nas discussōes, mas cujos argumentos tendem a ser bem considerados pelos demais; e (b) aqueles que se manifestam com freqüência, mas cujas opiniōes são pouco influentes. Os demais membros do Conselho participam em geral na condição de espectadores e só se manifestam nas votaçōes - cujos resultados, aliás, são potencialmente capazes de determinar, uma vez que constituem a maioria. Somente a experiência continuada de participação no Conselho permite antecipar, até certo ponto, o voto daqueles que integram esse segmento silencioso e heterogêneo.

Se essa antecipação pode ser razoavelmente bem-sucedida quando a ordem do dia contempla assuntos mais corriqueiros, a experiência anterior não era capaz de abarcar a complexa articulação de princípios e valores contraditórios suscitada pelas políticas afirmativas. É possível sugerir, assim, que a enorme tensão que perturbava o Conselho Universitário naquele dia resultava sobretudo do insuportável grau de imprevisi- 
bilidade de uma deliberação cuja natureza específica não tinha correlato anterior. De modo significativo, nenhum dos conselheiros que compóem a "linha de frente" ousava assumir a liderança do debate. $\mathrm{E}$ isso talvez não em virtude de uma improvável indefinição pessoal sobre o tema, mas antes pela dificuldade de avaliar as posições que seriam assumidas pelos demais conselheiros, isto é, o peso e as proporçōes dos diferentes pontos de vista no plenário.

Se essa interpretação é pertinente, não é fortuito que o maior número de manifestaçôes tenha partido de conselheiros que gozam de menor prestígio e que o debate sobre o mérito da proposta tenha sido travado num primeiro momento entre os representantes discentes. Além da posição de inferioridade relativa que ocupam no Conselho - cujo contraponto é uma maior liberdade de opinião -, os estudantes expressavam posiçôes coletivas consignadas em documentos. Um manifesto do Diretório Central dos Estudantes, lido pela representante discente $\mathrm{C}(\mathrm{CE})$, reafirmava a posição contra as cotas para negros estabelecida no último congresso da União Nacional dos Estudantes e reivindicava que a matéria não fosse votada. Em contraponto, o estudante de Direito $\mathrm{D}(\mathrm{CE})$ leu uma declaração, assinada por seis dos representantes discentes no Conselho (quatro titulares e dois suplentes), defendendo a implantação de cotas para estudantes negros. $\mathrm{O}$ estabelecimento de cotas para a escola pública não recebia o mesmo apoio, sob a alegação de que a medida não contribuiria para "reverter o sucateamento" da rede pública de ensino.

Tal posição, no entanto, restringia-se àquele grupo de estudantes. Como foi dito acima, o apoio à escola pública era justamente a forma pela qual diversos conselheiros expressavam seu desagrado com a adoção de cotas para estudantes negros (e, por extensão, às cotas em geral). Somente uma conselheira da "linha de frente", $\mathrm{E}(\mathrm{CP})$, manifestou-se diretamente contra as políticas afirmativas. Também ela, porém, falava num tom baixo e hesitante, que constrastava com sua veemência habitual, e 
teve o cuidado de demarcar a diferença entre suas convicçóes íntimas e o seu voto, que deveria traduzir o pensamento do segmento que representava no Coun.

Em termos mais gerais, é possível sugerir que a ênfase na representação de uma coletividade, tanto quanto a apresentação de posições coletivas propriamente ditas, era o que permitia aos conselheiros certa liberdade de manifestação num contexto em que ainda era muito difícil antecipar qual seria a repercussão de seus pontos de vista. Quanto a esse aspecto, é significativo que os servidores técnico-administrativos, habituados a atuar em bloco, tenham permanecido à margem do debate. Logo no início da sessão, um dos servidores registrou a indiferença do sindicato da categoria ao debate sobre políticas afirmativas. Em relação àquela matéria, portanto, não havia uma posição coletiva a defender.

A oposição individual mais veemente ao Plano de Metas partiu de um conselheiro recém-empossado, $\mathrm{F}(\mathrm{CP})$, a quem a condição de estreante conferia pouca credibilidade, e cujo tom exaltado, contrário à praxe bem mais sóbria dos debates no Coun, provocou sorrisos. O cerne do argumento, porém, já havia sutilmente pontuado outras manifestações. "O termo racial para mim é inaceitável", esbravejou. "Estaremos estabelecendo o racismo entre nós, tal como ocorre nos Estados Unidos e na Europa." Também ele apresentou sua posição por escrito, solicitando que o texto fosse reproduzido em ata. ${ }^{20}$

De modo geral, contudo, os argumentos oblíquos prevaleciam. E, dentre esses, os que levantavam restriçóes às cotas para negros tinham superioridade numérica. Por outro lado, o apoio ao Plano de Metas reunia não apenas aqueles conselheiros que se colocavam ao lado da reitoria em qualquer circunstância, mas também alguns membros destacados do Conselho. Era o caso, por exemplo, do conselheiro G(CD), que chegou a sugerir a ampliação das medidas propostas, e do conselheiro $\mathrm{H}(\mathrm{CP})$, decano do Coun, cuja defesa apaixonada da escola pública não 
desconsiderava as cotas para negros. Embora raramente compareça às sessões, o conselheiro $\mathrm{A}(\mathrm{CD})$ também pode ser considerado um integrante da "linha de frente", e soube capitalizar sua condição de especialista na matéria em intervenções que enfraqueceram os argumentos relativos aos fundamentos jurídicos da política de cotas. Não cabe à etnografia estabelecer se os argumentos "técnicos" - ou quaisquer outros - eram ou não capazes de modificar as intenções de voto de outros conselheiros. Sugiro todavia que a eficácia de determinados argumentos defendidos por conselheiros de sólida reputação residia em sua capacidade de limitar o campo dos argumentos possíveis, compelindo os opositores a buscar outra linha de raciocínio para conferir legitimidade a seus pontos de vista.

É provável que a avaliação do peso relativo das manifestações, mais que a contabilidade simples dos argumentos contra e a favor das políticas afirmativas, tenha sido decisiva para que a presidência colocasse a matéria em votação. Conforme o que havia sido estabelecido no início da manhã, as pessoas não-integrantes do Conselho foram convidadas a se retirar e o fizeram rapidamente e em silêncio (nas demais sessões, porém, a norma seria esquecida). O ponto a ser votado era simples, mas definitivo: os conselheiros favoráveis à adoção de políticas afirmativas por meio de um Plano de Metas de Inclusão Racial e Social deveriam votar "sim". A vitória do "não" sepultaria o projeto.

Formalmente, não estava em jogo nesse momento o conteúdo da proposta, mas tão-somente a existência ou não de uma política de ação afirmativa na UFPR. Era evidente, porém, que a aprovação desse ponto genérico significava de fato a aprovação das cotas no vestibular. A tensão entre os conselheiros havia chegado ao auge. Mesmo depois de horas de debate, a posição da maior parte dos presentes era desconhecida. Também não era possível antecipar como votariam aqueles que haviam se manifestado de forma mais ou menos direta contra as cotas para 
estudantes negros, mas não contra os demais aspectos do projeto. Nessas circunstâncias, talvez nem mesmo aqueles mais comprometidos com a proposição, pessoal e politicamente, contassem com a vitória quase unânime (apenas três votos contra) registrada na apuração.

O reitor ensaiou colocar em votação outros dois pontos: o prazo de duração da reserva de vagas e a fase do vestibular em que as cotas deveriam ser aplicadas. Foi dissuadido pelos murmúrios de reprovação no plenário, já que a própria existência das cotas não havia sido formalmente aprovada. Com uma frase de efeito, o conselheiro A(CD) sintetizou uma percepção mais geral, mas que certamente não tinha o mesmo significado para todos. "Este é um grande momento: decidimos começar a decidir", disse. "Agora precisamos enfrentar as nossas diferenças." Na sessão seguinte, de fato, as posições divergentes se tornariam mais firmes e mais explícitas.

\section{A segunda sessão: em busca da previsibilidade}

A segunda sessão temática do Conselho Universitário da UFPR sobre o Plano de Metas de Inclusão Racial e Social foi marcada para as $8 \mathrm{~h} 30 \mathrm{~min}$ do dia seguinte (7/5/2004, sexta-feira). O intervalo entre as sessões, porém, não foi apenas uma interrupção protocolar. Ao permitir a (re)composição de alianças, argumentos e estratégias de intervenção nos debates, esse intervalo foi também uma etapa, tão decisiva quanto as reuniōes formais, no curso das deliberações sobre as políticas afirmativas.

Dessa vez não havia controle na portaria do prédio. Tanto jornalistas quanto representantes do movimento negro tiveram acesso livre à sala do Conselho Universitário, cujos membros foram chegando aos poucos e ocupando seus assentos habituais. No total, compareceram 41 titulares e sete suplentes. ${ }^{21}$ Apesar dos gestos contidos e do tom baixo das 
conversas, a atmosfera pesada do primeiro dia começava a se dissipar entre os conselheiros. Já os membros da comissão responsável pelo Plano de Metas (um dos quais, em contraste com o habitual, usava um penteado de inspiração africana, num manifesto silencioso a favor das cotas) davam sinais de profunda ansiedade.

Ao abrir os trabalhos, o reitor apresentou, em forma de perguntas, os pontos a serem definidos naquela sessão: Quais seriam as políticas afirmativas? A quem seriam destinadas? Como seriam implantadas? E por quanto tempo? Em seguida, propôs duas opções de encaminhamento: (a) tomar como referência a proposta de resolução apresentada pelo relator; ou (b) responder às questóes enunciadas para somente depois redigir o texto correspondente. A primeira opção, como é evidente, favorecia a aprovação de uma política baseada em cotas; a segunda, ao contrário, comportava um grau de abertura que, na prática, remetia o debate novamente à estaca zero. Depois de algumas manifestaçóes do plenário - somente uma contrária à discussão do texto do relator -, o tema foi colocado em votação. A primeira alternativa prevaleceu, mas o placar de 23 votos a 13 indicava que pelo menos um terço dos conselheiros presentes não via com simpatia a política de cotas, pelo menos não nos termos propostos.

O próprio título da resolução - Plano de Metas para Inclusão Racial e Social - ocupou quase uma hora de debates. Conforme sua eloqüente manifestação no dia anterior, o conselheiro $\mathrm{F}(\mathrm{CP})$ fez uma longa digressão em defesa da retirada do texto da palavra raça e de seus correlatos. "Se eu fosse negro, eu me sentiria insultado", disse. "Ou nos colocamos como iguais, ou não nos verão como iguais. Sou favorável a tudo [o que a proposta contém], desde que se retire o termo racial." Colocava-se em questão, assim, o próprio sentido da noção de igualdade, como ideal moral e princípio político (eqüidade) ou como atributo substantivo (o igual entendido como idêntico). A reflexão acerca do(s) 
sentido(s) da igualdade, entretanto, não prosperou. Em vez disso, o conselheiro I(CP) propôs, em nome do "bom andamento dos trabalhos", o controle do tempo das manifestações - que seria aplicado seletivamente em alguns momentos.

Surgiu então o tema da articulação entre "raça" e "classe", que dividiu o plenário. Para alguns conselheiros, as dificuldades de acesso de estudantes negros à universidade resultavam antes de condiçôes socioeconômicas gerais que de preconceito e discriminação racial. Outros, apoiados em dados sociológicos oferecidos pelo relator em seu parecer, defendiam o ponto de vista contrário. Naquele contexto, porém, a palavra da servidora negra $\mathrm{K}(\mathrm{CT})$ tinha maior peso relativo que as ponderações daqueles cujo prestígio advinha de sua posição institucional, de suas credenciais acadêmicas ou de sua boa performance no Coun. "Colocar racial não é sinal de desrespeito, mas de coragem de enfrentar o fato de que o racismo existe", afirmou a conselheira, sugerindo que os representantes do movimento negro fossem consultados. Com a anuência do plenário, a presidência deu a palavra à coordenadora de uma das entidades presentes - jovem socióloga graduada na própria UFPR. Seu emocionado discurso contra o racismo excedeu em muito os três minutos previstos e chegou a impacientar parte dos presentes, mas possivelmente contribuiu para sensibilizar alguns conselheiros.

Outra dimensão da autoridade também tinha sua eficácia. Tal como no dia anterior, o conselheiro $\mathrm{A}(\mathrm{CD})$ se valeu de sua condição de jurista para lembrar que "a própria Constituição fala em raça". ${ }^{22}$ No mesmo registro, um dos integrantes da comissão responsável pelo Plano de Metas pediu a palavra para reiterar, como "especialista no assunto", a adequação do termo. Em votação, o título original foi aprovado por 31 votos a 5. Passou-se então à discussão do preâmbulo da resolução, que apresentava as justificativas gerais para a implantação do Plano de Metas de Inclusão Racial e Social. O texto foi aprovado com alterações pontuais. 
Definido o preâmbulo, o relator fez a leitura dos nove artigos do primeiro capítulo da proposta de resolução, que dispunham sobre o estabelecimento das cotas e sobre as condiçóes de acesso às vagas reservadas. Os dois primeiros artigos, referentes respectivamente às cotas para negros e para estudantes da rede pública, monopolizaram o debate até o final da sessão. Embora algumas manifestaçôes iniciais tenham procurado reintroduzir o tema da interconexão entre discriminação racial e desigualdade socioeconômica, propondo a articulação entre as duas modalidades de reserva de vagas, o debate subseqüente passou ao largo dos fundamentos da política de cotas e de suas implicaçôes mais gerais. $\mathrm{O}$ plano da discussão foi estabelecido por uma sequiência de argumentos "técnicos" relativos à implantação do Plano de Metas, cuja uniformidade sugeria um acordo prévio - impressão que o lugar institucional dos que se manifestavam, todos diretores de setores acadêmicos, contribuía para reforçar. Ao mesmo tempo, as manifestações já não mostravam a insegurança que havia caracterizado a primeira sessão do Conselho. Enfim, tudo se passava como se a incômoda imprevisibilidade das deliberaçōes tivesse ficado para trás.

A primeira iniciativa partiu do conselheiro $\mathrm{L}(\mathrm{CD})$, um dos mais prestigiados integrantes da "linha de frente" do Conselho e que até então não havia se manifestado. Depois de alegar preocupação com a "sustentabilidade" do Plano de Metas, sugeriu que as cotas fossem implantadas "de forma progressiva". O conselheiro $\mathrm{M}(\mathrm{CD})$ reiterou o argumento do colega e, dando um passo adiante, sugeriu um percentual de $10 \%$ das vagas, a ser ampliado progressivamente até os $20 \%$ da proposta original, mas sempre "na medida dos recursos existentes". Propôs ainda a redução à metade do período de duração da política de cotas, de dez para cinco anos, por não haver "orçamento suficiente para garantir a permanência dos alunos". Numa pequena variação sobre o mesmo tema, o conselheiro $\mathrm{N}(\mathrm{CD})$ ofereceu duas alternativas para o que chamou de 
“escalonamento" da política de cotas: a definição de um percentual progressivo, tal como já sugerido, ou a implantação inicial em um pequeno número de "cursos-piloto". Também o conselheiro $\mathrm{O}(\mathrm{CD})$ reforçou a proposta de redução do prazo da política de cotas, mas sem oferecer outro argumento além de uma exclamação enfática: "Dez anos é muito tempo!”.

Neste ponto, a pedido da presidência, o pró-reitor de graduação (que também coordena o Núcleo de Concursos da UFPR, responsável pelo vestibular) fez uma longa exposição sobre as novas regras do processo seletivo. Pela primeira vez a universidade faria o concurso em duas fases: a primeira com provas objetivas sobre os conteúdos do Ensino Médio e uma segunda etapa com a prova de redação e provas dissertativas específicas conforme o curso escolhido pelo candidato. ${ }^{23}$ Assim, além de uma eventual progressividade, seria necessário decidir também em que fase do concurso as cotas seriam aplicadas. A sugestão do pró-reitor era que isso só ocorresse na segunda fase do vestibular. Desse modo, a aparente interrupção do concerto de propostas de "escalonamento" da política de cotas contribuía de fato para reforçar a posição defendida pelos diretores de setor. Como é evidente, o preenchimento das cotas na primeira fase do vestibular garante que todas as vagas reservadas sejam efetivamente ocupadas. Deixando-se para aplicá-las na segunda etapa, é grande a probabilidade de não haver número suficiente de candidatos em condições de preenchê-las, sobretudo nos cursos mais concorridos.

Por outro lado, o mecanismo sugerido pelo pró-reitor permitia reafirmar o princípio meritocrático como fundamento do processo de seleção, situando-o no interior da própria política de cotas. Ao responder antecipadamente às críticas quanto ao "despreparo" dos alunos admitidos "pela porta dos fundos", a proposta contava com a simpatia de muitos conselheiros. Mais que isso, fora defendida pelo próprio reitor ao final da primeira sessão. Nessas circunstâncias, foi acatada sem comen- 
tários pelo relator, ainda que uma parte de seu parecer tivesse sido dedicada justamente a demonstrar que o vestibular não avalia adequadamente o mérito dos candidatos. ${ }^{24}$

A opção pela segunda fase do vestibular - cuja aprovação já era certa - incidia drasticamente sobre a abrangência da política de cotas. Nesse sentido, tornava-se possível tomá-la como argumento contra a progressividade defendida pelos diretores. Uma tabela elaborada pelo relator com base nos dados do último vestibular demonstrava que, mesmo na ausência de "escalonamento", as vagas destinadas às cotas não seriam integralmente preenchidas num primeiro momento. Não sem ironia, demonstrar que a política de cotas teria alcance reduzido parecia favorecer sua aprovação. Um exemplo é suficiente: o curso de Direito diurno oferece 88 vagas e não teve nenhum candidato negro aprovado em 2004. Com a aplicação das cotas na primeira fase do vestibular, haveria 17 estudantes negros aprovados. Na segunda etapa, observados os coeficientes obtidos pelos candidatos no exame anterior, apenas quatro alunos negros seriam admitidos.

A proposta de "escalonamento" não contava com o apoio de todos os diretores de setor. É significativo, no entanto, que os diretores favoráveis ao projeto original - e que votariam de modo correspondente não tenham se manifestado durante a discussão desse ponto, evitando o confronto direto com os colegas e com o pró-reitor. $\mathrm{O}$ restante do debate ocorreu entre conselheiros distantes da "linha de frente" que, com apenas uma voz dissonante, também defenderam a limitação da política de cotas. A maior diversidade dos argumentos, no entanto, permitia inferir que o compromisso prévio em torno do "escalonamento" (assumido aqui como possibilidade) tinha alcance restrito a determinadas posições institucionais. Seja como for, consolidava-se a impressão de um razoável consenso contrário à proposta do relator. De certo modo, é possível sugerir que a não manifestação dos conselheiros que apoiavam o 
projeto original contribuiu para criar uma impressão de previsibilidade que, no decorrer da votação, seria gradativamente desfeita.

A aplicação das cotas na segunda fase do vestibular foi aprovada por ampla maioria (35 votos a 4). A questão seguinte, que colocava em foco a própria natureza das políticas afirmativas na UFPR, dividiu os conselheiros. As cotas para negros deveriam estar associadas a critérios socioeconômicos? Por 21 votos a 16, prevaleceu o entendimento do relator, segundo o qual a autoclassificação racial seria o único critério de candidatura às vagas reservadas. $\mathrm{O}$ terceiro ponto a ser votado era a proposta de "escalonamento": reserva de $10 \%$ das vagas do vestibular para negros pelo período de cinco anos, com a possibilidade de aumento até $20 \%$. Pela primeira vez o parecer do relator era confrontado de forma direta, e mais, pela "linha de frente" do Conselho.

Os conselheiros posicionavam lentamente seus cartões. ${ }^{25} \mathrm{O}$ próprio reitor votou pela redução do percentual das vagas destinadas às cotas, revelando que os cumprimentos dirigidos ao relator na primeira sessão não significavam um apoio incondicional a seu parecer. Não era possível, porém, contabilizar de relance os votos dos demais conselheiros. Um silêncio pesado dominou a sala enquanto era feita a apuração, que indicou o mais indesejável dos resultados e o único que ninguém teria podido antecipar: o jogo do "escalonamento" tinha terminado em empate de 20 votos a 20. O secretário do Conselho rompeu a perplexidade generalizada: "Vamos fazer a recontagem". Em voz alta, procedeu mais uma vez à soma dos votos, desta vez indicando a vitória da proposta do relator pela diferença mínima de 21 votos a 19.

Aplausos dos representantes do movimento negro e dos membros da comissão responsável pelo Plano de Metas comemoraram a decisão. Naquele momento, ninguém sabia ao certo o que havia ocorrido e parecia provável que a primeira apuração tivesse sido equivocada. Mais tar- 
de, um dos conselheiros confidenciou que havia mudado seu voto na última hora. Peça fora do xadrez das alianças, coube a um estudante, cujo mandato se encerraria no mês seguinte, derrotar a "linha de frente" do Conselho Universitário. A etnografia não pode determinar as razões "últimas" que o levaram a reposicionar seu cartão na recontagem dos votos. A própria impulsividade do gesto sugere que as consideraçôes "políticas" embutidas na proposta original, assim como os argumentos "técnicos" que sustentavam a limitação do sistema de cotas, tiveram um papel reduzido na escolha que definiu o ponto mais crucial do Plano de Metas. Contrariando todo o cálculo da probabilidade objetiva de aprovação de uma ou outra das propostas, as particularidades da ação individual foram determinantes nesse momento. Pode-se dizer o mesmo em relação à iniciativa do secretário de iniciar rapidamente a recontagem dos votos. Embora sua intervenção tenha sido decisiva para a manutenção da política de cotas conforme a proposta original, é possível afirmar com razoável segurança que sua conduta foi orientada por razōes alheias ao conteúdo do Plano de Metas. Ao propor uma segunda apuração, o secretário evitava que o reitor, como presidente do Conselho Universitário, fosse obrigado a dar o voto de desempate. Embora sua preferência pela limitação da reserva de vagas já tivesse sido explicitada no primeiro escrutínio, a natureza decisiva do segundo voto teria efeitos incontornáveis, dentro e fora do Coun, ao indicar certa ambigüidade da administração superior acerca da política de cotas.

Não pretendo sugerir que o resultado das deliberações tenha sido determinado unicamente por razóes contingentes. $\mathrm{O}$ impasse inicial só pôde existir como resultado de uma correlação de forças específicas e de estratégias conscientemente articuladas nos limites de uma certa "regra do jogo". No entanto, não é menos certo que as coincidências fortuitas e os gestos impensados, elementos constitutivos da política como da vida so- 
cial em geral, tiveram, talvez mais que em outros contextos, um peso decisivo na aprovação das políticas afirmativas na UFPR. Não me refiro apenas ao resultado da votação acima, mas também às decisões subseqüentes.

De fato, as circunstâncias particulares daquela sessão do Conselho Universitário ajudam a compreender a relativa desimportância atribuída a dois aspectos que, em outras instituições, suscitaram acirradas polêmicas internas e ampla repercussão externa, inclusive na esfera judicial: (a) a definição de "afro-descendente"; e (b) o estabelecimento dos critérios para a inscrição às vagas reservadas para esse segmento no vestibular. Ainda sob o impacto da votação precedente, a proposta do relator foi aprovada em poucos minutos, sem nenhuma ponderação de caráter substantivo, com a seguinte redação:

Art. $1^{\circ}$ Disponibilizar, por um período de 10 (dez) anos, 20 (vinte) por cento das vagas dos processos seletivos da Universidade Federal do Paraná (UFPR), para estudantes afro-descendentes, em todos os cursos de graduação, cursos técnicos e de ensino médio oferecidos por esta Instituição.

$\$ 1$ o Serão considerados afro-descendentes, para os efeitos desta Resolução, os candidatos que se enquadrarem como pretos ou pardos, conforme classificação adotada pelo Instituto Brasileiro de Geografia e Estatística (IBGE). $\$ 2^{\circ}$ No ato da inscrição aos processos seletivos da UFPR, o candidato afro-descendente que desejar concorrer às vagas previstas no caput deste artigo deverá fazer a opção no formulário de inscrição e fazer a autodeclaração do grupo racial a que pertence.

Cabe mencionar que a proposta da comissão que elaborou o Plano de Metas, assim como a dos antropólogos da UnB que lhe serviu de inspiração, falava em "negros". O termo foi substituído por "afro-descendentes" pelo relator, reproduzindo assim a resolução sobre cotas da Universidade do Estado da Bahia (constante do processo), inclusive no 
que diz respeito à definição de "afro-descendente" ${ }^{26}$ Por outro aspecto, no entanto, a intervenção do relator contribuiu para reaproximar a política da UFPR à proposta original dos antropólogos da UnB. O texto submetido ao plenário estabelecia a autodeclaração como critério exclusivo para a inscrição dos candidatos às vagas reservadas, ${ }^{27}$ eliminando as sanções previstas pela comissão por "declaração falsa ou fraudulenta" ${ }^{28}$

O estabelecimento de cotas para estudantes oriundos do ensino público (artigo $2^{\circ}$ do projeto) não suscitava resistência. Ao contrário, a defesa da escola pública tinha sido justamente um dos argumentos centrais daqueles que se opunham à reserva de vagas para negros. Ainda assim, a votação só foi encaminhada depois de manifestações de nove conselheiros, o que contribuía para assegurar a previsibilidade que faltara ao escrutínio anterior. Duas sugestões destinadas a estreitar relações com a escola pública foram incorporadas pelo relator. Uma terceira proposição, no entanto, provocou desconforto no plenário: argumentando que a política de inclusão deveria se estender a todas as instâncias da universidade, o conselheiro $\mathrm{P}(\mathrm{CT})$ propôs a adoção de cotas também nos programas de pós-graduação e nos concursos para a contratação de servidores. Discrepante da concepção original do Plano de Metas, que limitava implicitamente o campo das variações possíveis, e formulada por um membro de menor peso relativo nos quadros do Coun, a proposta foi simplesmente ignorada pela mesa e pelos demais conselheiros.

A posição dos representantes discentes contra o estabelecimento de cotas para estudantes da rede pública já era conhecida desde o dia anterior. Desse modo, a maior novidade foi a intervenção do conselheiro $\mathrm{Q}(\mathrm{CD})$, ativo integrante da "linha de frente" do Conselho, que faltara à primeira sessão e que até então não havia se manifestado. "Quero que conste em ata que o relator e a procuradora-geral entendem que é preciso primeiro criar os problemas para depois tentar resolvê-los. A resolução só garante o acesso, não a permanência. Sou favorável a tudo, menos à 
hipocrisia." A manifestação tardia de um conselheiro que repetidamente enfatiza, com ironia, o próprio conservadorismo, foi recebida pelo plenário como provocação e não alterou o curso do debate. Quando a questão da permanência voltou a ser discutida na sessão seguinte, aliás, ele mesmo defendeu que qualquer programa de apoio acadêmico deveria ser dirigido a todos os alunos da universidade (e não, de modo específico, aos cotistas). Também opinou contra a concessão automática (ou preferencial) de bolsas aos alunos que ingressassem pelo sistema de cotas.

A votação ocorreu em duas etapas. Primeiramente, foi submetida ao plenário a proposição dos representantes discentes de retirada do artigo que estabelecia cotas para estudantes oriundos da escola pública. Sem surpresa, o destaque foi rejeitado, se é possível dizer assim, por unanimidade, já que os nove votos contrários eram justamente os dos defensores da proposta. $\mathrm{O}$ artigo foi aprovado em seguida por 26 votos a 14 , estabelecendo a reserva de $20 \%$ das vagas ofertadas nos processos seletivos da UFPR, por dez anos, para estudantes que tivessem cumprido o ensino fundamental e médio "exclusivamente em escolas públicas" (art. $\left.2^{\circ}, \$ 1^{\circ}\right){ }^{29} \mathrm{~A}$ vitória tranqüila em termos numéricos não escondia a natureza controvertida da matéria em discussão: o número de votos contrários nas deliberações rotineiras do Conselho Universitário tende a ser insignificante.

Já era tarde e os conselheiros não escondiam o cansaço. A sessão foi suspensa até a segunda-feira seguinte. Tal como anteriormente, porém, o intervalo formal não interrompeu a discussão sobre o Plano de Metas. $\mathrm{Na}$ segunda-feira, ficou claro que o fim de semana não havia sido dedicado apenas ao lazer. 


\section{A terceira sessão: o "técnico" e o "político"}

A terceira sessão do Conselho Universitário da UFPR sobre o Plano de Metas de Inclusão Racial e Social, realizada na manhã do dia 10 de maio de 2004, começou num clima de relativa tranqüilidade, ao menos em comparação com as duas anteriores. Não havia controle na portaria do prédio e o número de jornalistas e representantes do movimento negro era menor. Os próprios membros do Conselho se permitiram um pequeno atraso. Aparentemente, os aspectos mais difíceis já haviam sido vencidos, e a sessão não reservava nenhuma surpresa. As vagas para estudantes indígenas, primeiro ponto a ser definido, não despertavam interesse ou preocupação. Tanto os debates sobre o Plano de Metas realizados previamente na universidade quanto as reportagens da imprensa costumavam "esquecer" de mencionar essa dimensão da proposta de políticas afirmativas.

$\mathrm{Na}$ abertura da sessão, pouco antes das 9 horas, havia 45 conselheiros titulares e apenas cinco suplentes. $\mathrm{O}$ conselheiro $\mathrm{A}(\mathrm{CD})$, um dos principais defensores do Plano de Metas nas duas primeiras sessões, não compareceu. Todos os demais diretores de setores acadêmicos, no entanto, estavam presentes. A discussão foi retomada a partir do artigo $3^{\circ}$ da proposta de resolução. ${ }^{30}$ Se a comissão responsável pelo Plano de Metas havia se limitado a apontar a existência de vagas para estudantes indígenas - reproduzindo a proposta dos antropólogos da UnB -, o texto do relator explicitava as condiçóes de oferta de tais vagas e os mecanismos para seu preenchimento. Nesse sentido, a política relativa a estudantes indígenas era a mais detalhada das três vertentes do Plano de Metas, mas foi a que suscitou menor número de comentários.

Além de perguntas que indicavam o completo desconhecimento do tema - "eles falam português? sabem assinar?" -, outro aspecto chama a atenção. Em contraste com o esforço concertado de limitação das cotas 
para negros e estudantes oriundos da escola pública, alguns conselheiros defenderam o aumento do número de vagas para estudantes indígenas. De acordo com a proposta do relator, haveria cinco vagas nos dois primeiros anos, número que seria elevado progressivamente nos anos seguintes. As vagas para estudantes indígenas seriam suplementares à oferta geral do vestibular e seriam preenchidas por meio de processo seletivo específico. $\mathrm{O}$ caráter gradual da política levava em consideração o acompanhamento acadêmico individualizado dos estudantes e os custos do programa de permanência a ser implantado (bolsas, moradia, transporte e alimentação). ${ }^{31}$ Em menos de meia hora, o artigo foi aprovado com apenas cinco votos contra.

Talvez seja possível sugerir neste ponto que, a despeito da invisibilidade dos índios no debate sobre o Plano de Metas, o tom cauteloso da proposta do relator para os estudantes indígenas tenha inspirado indiretamente a movimentação em torno do "escalonamento" da reserva de vagas para negros e estudantes de escola pública na sessão anterior. Como se viu acima, não apenas a progressividade esteve presente na argumentação de todos os conselheiros que se manifestaram contra o percentual das cotas destinadas a esses dois segmentos, como a justificativa apresentada insistia nas limitações orçamentárias para a implantação do Plano de Metas. Convém assinalar, no entanto, que a proposta do relator não previa a concessão obrigatória de bolsas para os alunos cotistas, ponto que figurava apenas na proposta relativa aos estudantes indígenas. É bastante claro que, desde o início da discussão, tratava-se tão-somente de limitar o alcance da política de cotas - propósito que, como se verá adiante, não foi sepultado pelo desconcertante empate na votação de sexta-feira ou pelas contingências que garantiram a manutenção do percentual original.

Dando prosseguimento aos trabalhos, o relator apresentou os artigos que definiam os mecanismos de classificação dos candidatos e da aplica- 
ção das cotas (artigos $4^{\circ}$ a $9^{\circ}$ ). Imediatamente depois de encerrada a leitura, a presidência comunicou ao plenário que havia recebido uma emenda substitutiva ao texto do relator. Tendo sido definido anteriormente que a aplicação das cotas se daria na segunda etapa do vestibular, o que estava em jogo nesse momento era o processo de preenchimento das vagas reservadas. De acordo com a proposta do relator, 60\% das vagas disponíveis em cada curso seriam preenchidas pelos primeiros classificados, independentemente da opção ou não pelas cotas. Somente depois seriam ocupadas as vagas restantes, $20 \%$ pelos candidatos afro-descendentes e $20 \%$ pelos oriundos da escola pública - mecanismo similar ao adotado, por exemplo, pela Universidade do Estado da Bahia (Uneb). ${ }^{32}$

O substitutivo apresentado pelo conselheiro $S(C D)$, diretor da Escola Técnica da UFPR, propunha a inversão do processo. A partir da classificação dos candidatos na primeira fase do vestibular, as primeiras vagas a serem ocupadas seriam as reservadas a afro-descendentes e estudantes de escola pública. Somente depois da aplicação das cotas, é que seriam preenchidas as vagas de classificação geral. A diferença, à primeira vista desprezível, é significativa. $\mathrm{O}$ mecanismo sugerido pelo relator possibilitava que, conforme seu desempenho nas provas, estudantes que tivessem se candidatado às cotas fossem aprovados nas vagas de classificação geral. Assim, ao menos em tese, a relação dos aprovados poderia ter mais que $20 \%$ de candidatos originalmente inscritos para as cotas. Já o substitutivo teria efeito oposto: ao estabelecer o preenchimento antecipado das cotas, o percentual de $20 \%$ funcionaria na prática como um teto para a admissão dos candidatos inscritos nos termos do Plano de Metas.

A razão invocada para justificar a iniciativa era a necessidade de "manter o mais alto padrão dos alunos ingressantes" e, desse modo, evitar críticas ao programa de cotas. De acordo com a exposição de motivos 
do conselheiro S(CD), a proposta do relator "levaria, inevitavelmente, a um rebaixamento da média de ingresso dos optantes". O argumento carecia de fundamento objetivo, já que a eventual aprovação de um percentual superior de alunos dos segmentos beneficiados pelas cotas só poderia ocorrer justamente a partir de um bom desempenho nas provas. Não houve, no entanto, nenhum comentário a esse respeito. Um segundo aspecto também merece atenção. A proposta do relator já estabelecia que as chamadas complementares obedeceriam à ordem de classificação geral no vestibular, independentemente da opção pelas cotas. O substitutivo mantinha esse procedimento, mas a argumentação (cujos tropeços de concordância verbal indicavam ter sido redigida às pressas) dava a entender o contrário: "Em relação às chamadas complementares, se mantidas as cotas, a identificação dos candidatos seria inevitável e além disso a diferença do desempenho entre optantes e não optantes poderia estar muito acentuada e este fato criará uma série de embaraços que poderão comprometer o programa”. Também aparece aqui pela primeira vez a intenção de diluir os cotistas no conjunto geral dos alunos a pretexto de evitar discriminação - que também revela, por outro lado, uma representação negativa das cotas como forma legítima de acesso à universidade.

Recebida com serenidade pelo plenário - o que autoriza sugerir que não era inteiramente inesperada -, a emenda representava um segundo passo do movimento que, sem contradição, visava ao mesmo tempo estabelecer políticas afirmativas na UFPR e limitar o seu alcance. Se a sucessão de intervenções em defesa do "escalonamento" do programa de cotas, na sessão anterior, deixava até certo ponto em aberto a existência de um acordo de bastidores, assim como seu alcance, a apresentação do substitutivo não podia ser considerada, mesmo pelos conselheiros mais desatentos, como simples expressão individual de um colega cujo apoio irrestrito à administração era bem conhecido de todos. Assumindo a possibilidade de uma articulação, já que o registro etnográfico não pode 
determinar o que "realmente" aconteceu no intervalo entre as sessões, parece razoável supor que a operação não poderia ser levada a cabo por um membro qualquer do Conselho. Minha sugestão é que ninguém senão o próprio diretor da Escola Técnica reunia as condiçõos para assumir esse papel, não somente por seus atributos individuais, mas sobretudo pela peculiaridade de sua posição na universidade e no próprio Conselho.

Conforme indiquei anteriormente, os diretores de setores acadêmicos constituem o segmento politicamente mais forte do Coun e o único efetivamente capaz de determinar, ao menos até certo ponto, o curso das deliberações. Nesse sentido, as chances de sucesso de uma articulação são diretamente proporcionais ao envolvimento dos diretores (mesmo que a iniciativa não tenha origem nesse grupo), como aliás se evidenciou no debate sobre o "escalonamento" da política de cotas. E ainda que seus pontos de vista não sejam homogêneos, os diretores mantêm entre si uma mutualidade engendrada pela própria posição institucional. Assim, seria desconfortável para qualquer um deles assumir uma posição explícita e formal contra o parecer do relator - um colega prestigiado no grupo -, especialmente numa matéria de interesse direto da administração superior.

O diretor da Escola Técnica ocupa uma posição diferenciada nesse quadro. Seu cargo se equipara aos dos demais diretores, o que lhe confere um lugar institucional distintivo. Ao mesmo tempo, porém, a natureza de sua função também o distingue do conjunto dos diretores, uma vez que a Escola Técnica tem um caráter subsidiário em relação às atividades acadêmicas de graduação e pós-graduação. Nesse sentido, seu lugar institucional não tem equivalente em termos estruturais, peculiaridade que se revela no relacionamento cotidiano com os demais diretores e também no âmbito do Conselho Universitário. Se ele pode desfrutar de certa superioridade diante dos conselheiros que não detêm cargos 
administrativos, encontra-se ao mesmo tempo suficientemente distante dos demais diretores para que as obrigações de reciprocidade no interior desse grupo o afetem de modo menos intenso.

Assim, proponho que somente o diretor da Escola Técnica poderia reunir as condições necessárias - uma conjugação ótima entre proximidade e distância, tanto da administração superior quanto dos demais diretores e de outros conselheiros - para expressar uma oposição formal ao parecer do relator do Plano de Metas e para sustentá-la no plenário com chances objetivas de reunir maioria na votação. Às suas qualidades de posição se somavam seus atributos de orador e sua experiência como ex-parlamentar. Nessas circunstâncias, torna-se ainda mais significativo o silêncio dos diretores de setores acadêmicos: as manifestações a favor da emenda substitutiva partiram majoritariamente de conselheiros de menor prestígio institucional e pessoal.

Até certo ponto, a discussão sobre a forma de preenchimento das cotas era vã, uma vez estabelecido que isso ocorreria na segunda fase do vestibular. Como havia indicado a tabela elaborada pelo relator, qualquer que fosse o mecanismo adotado nessa fase, seria muito difícil atingir o percentual de $20 \%$ de candidatos negros aprovados num primeiro momento de vigência da política de cotas. Se o efeito prático da proposta do diretor da Escola Técnica era reduzido, isso não diminuía a eficácia de suas implicações políticas nos diferentes planos em que o debate se situava. O substitutivo foi exaustivamente debatido e praticamente monopolizou a sessão. E se sua apresentação visava garantir a previsibilidade das últimas decisóes sobre a política de cotas, a dinâmica do debate suplantou os movimentos ensaiados e a solenidade ritualística, fazendo emergir as segmentações, estratégias e motivações que até então haviam estado presentes de modo relativamente indireto e implícito.

A primeira rodada de argumentação pôs em relevo inicialmente questões de princípio, mas ainda situadas num terreno que poderia ser qua- 
lificado como "técnico". Depois de algumas falas que expressavam certa incompreensão das diferenças entre as propostas, a presidência convocou mais uma vez o pró-reitor de graduação para prestar esclarecimentos sobre as novas regras do vestibular. Ao terminar a exposição "técnica", o pró-reitor deixou clara sua preferência - "política" - pelo preenchimento das cotas antes das vagas de classificação geral: "Assim estaremos escolhendo os melhores". Como é de praxe, o relator foi convidado a se pronunciar. Depois de explicar a diferença "técnica" entre as duas propostas, resumiu numa frase a distância "política" entre elas: "É simples, uma proposta abre e a outra fecha”. Expostas as diferenças dessa maneira, o próprio reitor decidiu opinar, colocando o debate num outro plano político, cujos horizontes não eram os fundamentos, mas as repercussões imediatas da política de cotas. "Se não preenchermos as cotas, qual o tratamento que será dado pela imprensa?"

A possibilidade de não preenchimento das vagas reservadas às cotas (o que de fato ocorreu) estava presente nos dois modelos, uma vez que dependia da existência de número suficiente de candidatos aprovados na primeira fase do vestibular. Tal como apresentada na discussão, porém, a proposta do relator parecia ao mesmo tempo favorecer o ingresso de candidatos menos qualificados e conduzir à sobra de vagas reservadas às cotas - paradoxo lógico que não parecia perturbar os conselheiros, empenhados em desfiar argumentos "técnicos" para defender posiçóes "políticas", ao mesmo tempo em que apresentavam preocupações "políticas" para apoiar mecanismos "técnicos".

O autor do substitutivo voltou a se manifestar: "Nós discutimos o percentual e o escalonamento, depois perdemos", afirmou. Pela primeira vez surgia no debate uma referência explícita a um "nós", isto é, a uma posição coletiva contrária à proposta do relator. Não por acaso, o diretor da Escola Técnica voltou a insistir num dos argumentos mais caros aos conselheiros: a qualificação dos candidatos. "Temos o compromisso 
da permanência dos alunos, e isto é mais difícil com o aluno que tenha média mais baixa. A permanecer a proposta do relator, estaremos garantindo mais que os $20 \%$ das cotas." O comentário suscitou protestos dos membros da comissão responsável pelo Plano de Metas. O pró-reitor interveio novamente, de um modo que fazia referência implícita a um entendimento prévio sobre o alcance que as políticas afirmativas deveriam ter. "O aluno tem de optar. Ele tem a opção de não optar pelas cotas. O relator garante $20 \%$ e mais. Não era esse o objetivo." Dessa vez, quem protestou foi o representante discente $\mathrm{T}(\mathrm{CE})$. "O argumento da qualidade está sendo usado maliciosamente para restringir a inclusão", afirmou, provocando a reação imediata do reitor: "Maliciosamente não é uma palavra a que esse Conselho esteja acostumado".

Os procedimentos ritualísticos do Conselho, bem como os argumentos alusivos, pareciam ter sido subitamente colocados em suspenso. Logo em seguida, a exposição do conselheiro $\mathrm{U}(\mathrm{CP})$ foi interrompida por um dos integrantes da comissão responsável pelo Plano de Metas - que, não sendo membro do Conselho, não tinha autorização para se manifestar, e menos ainda durante a fala de um conselheiro titular. Era hora de invocar o regimento - como norma de conduta e, ao mesmo tempo, como estratégia política. Na verdade, a questão de ordem contra a intervenção de não-membros do Conselho teria sido pertinente também nas sessões anteriores, mas só agora (tal como no início da primeira sessão) parecia necessário recorrer ao regimento para conter a imprevisibilidade do debate e, ao mesmo tempo, provocar os adversários.

A interrupção possibilitou o retorno ao registro anterior, isto é, ao plano "técnico". A conselheira E(CP) ofereceu um argumento novo, segundo o qual a proposta do relator viria em prejuízo dos próprios destinatários do Plano de Metas, pois o candidato à política de cotas cujo bom desempenho assegurasse sua aprovação na classificação geral estaria excluído dos benefícios do programa de permanência para os alunos 
cotistas. A esse respeito, o parecer mencionava apenas um "critério de classificação preferencial" para a concessão de bolsas de permanência aos alunos que ingressassem pela política de cotas. As únicas bolsas efetivamente previstas eram as que beneficiariam os estudantes indígenas. $\mathrm{O}$ argumento da conselheira, porém, provocou mais uma rodada de debates, cujo resultado foi a eliminação de qualquer referência à concessão de bolsas para os alunos cotistas. Também prevaleceu o entendimento contrário à criação de mecanismos específicos de apoio acadêmico.

De certo modo, o plenário acabava por dar razão à crítica feita na sessão anterior pelo conselheiro $\mathrm{Q}(\mathrm{CD})$ quanto à "hipocrisia" de uma política voltada ao ingresso, mas não à permanência dos cotistas. Embora a posição desse conselheiro seja indissociável do contexto dos embates políticos no interior da UFPR, cabe registrar que a desatenção à permanência dos alunos tem sido um ponto recorrente na reflexão dos cientistas sociais sobre o sistema de cotas, tal como implantado em universidades brasileiras - ver, por exemplo, Sansone (2005) e Lima (2005).

Restabelecendo a solenidade dos procedimentos, o reitor encerrou o debate e encaminhou a votação, que desta vez não trouxe surpresa: a emenda substitutiva foi aprovada por 25 votos a favor (incluindo os do reitor e da vice-reitora) e 14 votos contra. Todo o restante da discussão, sobre as formas de acompanhamento do programa e as disposiçóes transitórias, transcorreu de modo sereno e previsível. Ao encerrar a terceira e última sessão dedicada ao Plano de Metas - agora resolução no 37/04Coun -, o presidente agradeceu a todos pela aprovação de políticas afirmativas e convidou: "Vamos encerrar esta sessão com palmas". 


\section{A política de cotas e a lógica do sacrifício}

Um dos aspectos mais característicos das sessões do Conselho Universitário da UFPR sobre as políticas afirmativas é que o processo de deliberação, marcado por um forte componente ritualístico, comportava ao mesmo tempo um alto grau de abertura ao contingente, cuja consciência afetava profundamente a todos os participantes. Nesse sentido é pertinente evocar a sugestão de Mariza Peirano (2002), para quem a definição de ritual só pode ser adequadamente estabelecida em termos etnográficos.

Tal como já havia indicado Roberto da Matta no clássico Carnavais, malandros e heróis (1979), a autora observa que, se os rituais são "tipos especiais de eventos, mais formalizados e estereotipados" porque já recortados em termos nativos, eles não possuem uma natureza radicalmente distinta em relação aos demais eventos que constituem a dinâmica de uma determinada sociedade. Ainda segundo Peirano, tanto os rituais como os eventos críticos "ampliam, focalizam, põem em relevo e justificam o que já é usual” (Peirano, 2002, p. 8-9).

À luz dessas reflexões, o que chama a atenção no contexto aqui analisado é que o "ritual", ao tematizar determinados elementos da experiência social, não tinha como escopo reafirmá-los ou justificá-los. Em vez disso, tratava-se de transformar - por meio da formulação de uma norma à qual se atribuía eficácia material, política e moral - as relações entre a universidade, como instituição pública, e a sociedade mais ampla. Mais que isso, ao modificar seus procedimentos, especialmente no que se refere ao princípio universalista e (alegadamente) meritocrático do vestibular, a universidade projetava uma nova imagem da própria sociedade. A deliberação sobre o Plano de Metas era assim um ato de instituição - nos dois sentidos que a palavra comporta. 
Quando o Plano de Metas entrou na ordem do dia, minha expectativa era de que as reuniōes do Conselho Universitário explicitassem valores associados a diferentes concepções de igualdade e ao reconhecimento de diferenças. Num primeiro momento, portanto, surpreendeume a virtual ausência de um debate sobre os fundamentos da política de cotas e sobre a questão racial que, reconhecidamente, constituía o substrato do Plano de Metas. Essa interdição tácita não poderia ser considerada simplesmente o efeito da acumulação de escrúpulos individuais. Ao contrário, parece possível perceber nessa recusa sistemática a expressão de uma consciência difusa, mas não menos aguda, da sacralidade do próprio objeto das deliberaçôes - concebendo-se o sagrado, com Marcel Mauss, como tudo aquilo que, para o grupo e seus membros, qualifica a sociedade (1968[1906], p. 16-17).

É nesse sentido que me parece possível uma aproximação entre o processo de aprovação do Plano de Metas de Inclusão Racial e Social na UFPR e a lógica simbólica do sacrifício. Na perspectiva maussiana, o sacrifício constitui uma relação específica estabelecida pelos homens com o "mundo das coisas", que se pauta por rearticular, de uma maneira ou de outra, o sagrado e o profano numa mesma unidade construída pela destruição de "coisas" transformadas em vítimas sacrificiais. ${ }^{33}$

Sem desconhecer as limitações teóricas e empíricas de uma aproximação dessa natureza, sugiro que as deliberações sobre as políticas afirmativas na UFPR constituíram uma espécie de rito sacrificial cujo objeto era a própria representação da sociedade brasileira, indissociável da imagem na qual os próprios indivíduos, no plano da sociabilidade, reconhecem a si mesmos e aos outros como pessoas morais. Ao estabelecer a reserva de parte de suas vagas a segmentos sociais específicos, a universidade não apenas rearticulava suas relações práticas com os potenciais candidatos a ingressar na instituição, mas também concebia e 
qualificava de modo distinto a própria sociedade da qual é parte. No limite, o que estava em questão no debate sobre a política de cotas era a destruição ritual da fluidez classificatória como representação valorizada da sociedade brasileira, concomitantemente à projeção de uma nova imagem, de distinções mais nítidas, mas que veio a ser concebida como potencialmente mais justa. ${ }^{34}$

Nesse sentido, seria possível conceber o debate sobre o Plano de Metas ao mesmo tempo como um sacrifício expiatório e propiciatório, cujos efeitos só poderiam ser obtidos com a condição de demarcar fronteiras naquilo que, até então, podia ser pensado e (até certo ponto) vivido como misturado e indefinido. Entende-se assim a atmosfera perturbadora, característica das destruições rituais, na qual o debate se desenvolveu. Ainda na linguagem do sacrifício, é possível sugerir que as energias liberadas pela elaboração do Plano de Metas eram, de certo modo, incontroláveis. Assim, não é contraditório que o mesmo empenho dedicado pela administração superior da UFPR para assegurar a implantação de uma política de cotas tenha também se direcionado a mantê-la dentro de limites aquém ou além dos quais suas implicações eram tidas como potencialmente negativas. Se essa interpretação é pertinente, a invisibilidade dos índios ao longo de todo o processo talvez não deva ser creditada simplesmente ao desconhecimento ou ao desinteresse. Ainda que isso seja também verdadeiro, como indica a etnografia, é necessário considerar a diferença de natureza entre uma política de cotas e a destinação de vagas de caráter suplementar às que são ofertadas regularmente.

O registro das sessões do Conselho Universitário não somente evidencia o grau de excepcionalidade que caracterizou o processo de discussão das políticas afirmativas na UFPR - compatível com a periculosidade inerente aos ritos sacrificiais -, mas também permite apreender etnograficamente algumas formas concretas de expressão dessa excepcio- 
nalidade. Não é preciso recorrer à unidade constitutiva do sacrifício para indicar que as três sessões do Conselho foram, obviamente, momentos de um único processo. Mas cabe assinalar que tal articulação se tornou ainda mais profunda com a aprovação do regime de urgência, recurso regimental cujo efeito é garantir que, uma vez iniciadas, as deliberações não possam ser interrompidas. Nesse sentido, como se viu, até mesmo os intervalos entre as sessões foram etapas decisivas que incidiram diretamente no andamento das deliberações.

A relevância desses momentos intersticiais pode ser avaliada pelas diferenças qualitativas entre as três sessões do Conselho Universitário. $\mathrm{Na}$ primeira sessão, a despeito de todos os preparativos que antecederam a colocação do Plano de Metas na ordem do dia, o grau de imprevisibilidade se aproximava do insuportável. Logo de início, os seguidos apelos aos limites regimentais revelavam indiretamente a tensão suscitada pela abertura ao inesperado e/ou incontrolável. Ademais, se a política de reputações constitui, como sugeri, um aspecto central da dinâmica do Conselho, a discussão sobre as ações afirmativas colocava em relevo não somente as implicações políticas e administrativas das posições assumidas pelos conselheiros, mas também, no mais alto grau, sua reputação como pessoas morais.

Essas condiçóes propiciaram, ao menos até certo ponto, uma inversão de papéis e de condutas. A suspensão da sociabilidade que precede as sessões, a subordinação da "linha de frente" às iniciativas de conselheiros de menor prestígio e a insegurança de veteranos que se conduziam como neófitos são alguns exemplos. Também prosperavam os argumentos oblíquos que, constituindo uma polarização entre estudantes negros e alunos de escola pública, deixavam transparecer uma resistência às cotas em geral que, no entanto, jamais chegou a se manifestar abertamente. Não é possível desconhecer que, quanto maior a proximidade estrutural (não necessariamente política) com a administração superior, 
mais se tornava difícil rejeitar um projeto de sua iniciativa e interesse, havendo espaço apenas para reparos relativos a pontos específicos. Essas limitações, porém, só explicam parcialmente a solenidade exacerbada e a preferência pelas posições coletivas consignadas em documentos, que asseguram um distanciamento máximo entre idéias e pessoas, posições políticas e reputações morais.

A atmosfera era comparativamente menos perturbadora no segundo dia. Ao deslocar o debate para o terreno dos argumentos "técnicos", a movimentação em torno do "escalonamento" da política de cotas possibilitada justamente pelo intervalo entre as sessões - permitia passar ao largo de suas implicaçóes mais gerais. Ao mesmo tempo, o concerto de considerações "técnicas" assegurava até certo ponto maior previsibilidade às deliberações. $\mathrm{O}$ imponderável se reintroduziu de forma dramática com o empate na votação sobre o percentual e o prazo da reserva de vagas. Ainda que esse resultado tenha sido contingente, é possível tomá-lo, por sua carga simbólica, como expressão sintética não somente do equilíbrio precário entre o previsível e o contingente, mas também da força com que se opunham, naquele contexto, as representações de uma "totalidade" misturada ou composta por distinções mais nítidas e permanentes.

Por certo, como efeito dos desdobramentos da sessão anterior, a terceira sessão trouxe ao plenário uma emenda substitutiva que se opunha de modo formal à proposta do relator. Se esse passo pôde garantir, num primeiro momento, certa serenidade na condução dos trabalhos, à medida que se aproximava a votação os movimentos estudados deram lugar à nervosa explicitação de pontos de vista, divisões e estratégias que até então só haviam se manifestado de maneira indireta. O "político", em suas diferentes dimensões, voltava a prevalecer sobre o "técnico". Embora a matéria a ser definida - o mecanismo de aplicação das cotas - fosse comparativamente pouco relevante, seu significado 
ultrapassava amplamente as conseqüências práticas de um ou outro dos modelos propostos.

Voltando ao início, ainda que não seja adequado estabelecer uma definição a priori de ritual, pode parecer inoportuno e contraditório evocar a lógica dos ritos sacrificiais na análise de um contexto no qual os riscos da imprevisibilidade atingiram um grau tão elevado, tornando o encadeamento formalizado das diferentes etapas da discussão incapaz de prescrever ou de assegurar um resultado determinado. É possível sugerir, todavia, que a contradição é mais aparente que real. Se o jogo das forças que se opunham, em diferentes níveis, durante as deliberaçôes sobre o Plano de Metas, articulava-se como rito, no que se refere à solenidade dos movimentos, convém lembrar que a própria dinâmica dos ritos sacrificiais - como ensina Marcel Mauss - oferece uma abertura à contingência que se aproxima daquilo que comumente é definido como jogo. ${ }^{35} \mathrm{E}$ é assim que a consumação do rito não permite antecipar com segurança a natureza e o alcance de seus efeitos - questão empírica que permanece em aberto. Alguns desses desdobramentos, porém, já podem ser assinalados.

\section{O primeiro vestibular com cotas}

A exemplo do que ocorreu em outras instituições, a constitucionalidade do sistema de cotas não demorou a ser questionada. No início de agosto de 2004, poucos dias antes da abertura das inscrições ao vestibular, o procurador da República Pedro Paulo Reinaldin protocolou em Guarapuava (a 250 quilomêtros a oeste de Curitiba) uma ação civil pública contra as normas da UFPR, alegando incompatibilidade entre a reserva de vagas e o princípio constitucional da igualdade. A iniciativa do procurador teve grande repercussão na imprensa, mas não produziu 
conseqüências práticas. Em fevereiro de 2005, a Justiça Federal determinou a extinção da ação por razões formais. ${ }^{36}$

Os aspectos mais relevantes da primeira experiência de um vestibular com cotas tiveram lugar na própria universidade, sem repercussão pública imediata. Tal como na UnB, a implantação do sistema produziu um afastamento significativo em relação às normas aprovadas pelo Conselho Universitário. As conseqüências desse afastamento, porém, só vieram à tona durante a matrícula dos candidatos aprovados. E isso porque, há vários anos, a inscrição para o vestibular da UFPR é feita exclusivamente pela internet. Os documentos exigidos pelo edital do concurso são apresentados somente pelos candidatos aprovados, já no momento de confirmação da matrícula.

No que diz respeito à inscrição, o Edital no 01/2004 do Núcleo de Concursos da UFPR reproduziu estritamente as normas aprovadas pelo Coun. Os candidatos às vagas reservadas - negros e estudantes de escola pública - deveriam assinalar a opção correspondente no formulário eletrônico. Somente para os primeiros era também solicitada "a autodeclaração do grupo racial a que pertence", em espaço próprio do mesmo formulário.

Também a forma de classificação dos candidatos explicitada no edital correspondia aos mecanismos definidos pelo Coun. As normas referentes à divulgação dos resultados, por sua vez, tiveram origem em resolução aprovada pelo Conselho de Ensino, Pesquisa e Extensão (Cepe) um mês depois da discussão do sistema de cotas. Conforme a decisão do Cepe, a relação de cotistas não seria divulgada. ${ }^{37}$ Minha sugestão é que as condições estabelecidas para a matrícula dos aprovados - que serão explicitadas a seguir - podem ser compreendidas como um desdobramento lógico (mas não necessário) dessa opção pelo sigilo.

Expressando um ponto de vista que é também o meu (assim como o de muitos antropólogos), Livio Sansone propõe, em comentário sobre o primeiro vestibular com cotas da UnB, que as medidas de ação afir- 
mativa funcionem na base da autodeclaração, "sabendo que haverá algum abuso, mas que a pressão moral para que as pessoas não se digam negras sabendo não sê-lo funcionará como um eficiente desincentivo" (Sansone, 2005).

Se a opção pelo sigilo feita na UFPR afastou a possibilidade de controle público de eventuais abusos, conforme a sugestão de Sansone, esse espaço foi ocupado por normas que não faziam parte das resoluções aprovadas pelos Conselhos superiores da instituição. $\mathrm{Na}$ lista dos documentos a serem apresentados pelos candidatos classificados no vestibular, o Edital do Núcleo de Concursos estabeleceu a exigência, para os candidatos negros, de uma

declaração de próprio punho, perante autoridade constituída da UFPR, segundo modelo obtido no NAA [Núcleo de Assuntos Acadêmicos], de que o candidato pertence ao grupo preto ou pardo, constantes no Censo Oficial do IBGE, de que é assim reconhecido na sociedade e de que possui traços fenotípicos que o identificam com o tipo negro. (Edital no 001/2004NC, art. 69, alínea "e") 38

No artigo seguinte, o edital informava que uma comissão seria nomeada pelo reitor para analisar os documentos apresentados pelos classificados no processo seletivo, inclusive a "autodeclaração do grupo racial a que pertence o candidato, conforme previsto na alínea 'e' do Artigo 69". É inafastável neste ponto o paralelo com o caso da UnB, com uma diferença sutil. Se em Brasília coube à comissão designada, para analisar as fotografias dos candidatos, a tarefa de "mimetizar os olhos e filtros cognitivos da sociedade" (Maio e Santos, 2005a), no caso da UFPR, atribuía-se em primeiro lugar ao próprio candidato a responsabilidade de fazer coincidir sua autoclassificação racial com o reconhecimento "da sociedade". A tarefa da comissão seria a de avaliar essa correspondência. 
Não tive acesso à composição da comissão nem aos critérios e procedimentos por ela adotados, senão a partir do que foi publicado pela imprensa ou pelos órgãos oficiais de divulgação da UFPR. O mesmo vale para os resultados do processo seletivo. Desse modo, limito-me a um breve resumo dos acontecimentos, reservando uma análise mais minuciosa para trabalho futuro.

Foram aprovados 4.167 candidatos no vestibular de 2005. Desses, 573 haviam se candidatado às 831 vagas reservadas para negros. Sobraram portanto 258 vagas para negros, em 49 cursos. Em Medicina, por exemplo, das 35 vagas reservadas, 24 foram preenchidas. O ingresso de alunos negros no curso de Engenharia Civil foi ainda menor: das 35 vagas disponíveis, apenas 19 foram preenchidas. Com os estudantes de escola pública ocorreu o oposto. Foram aprovados 930 candidatos, isto é, 831 alunos ingressaram por meio da política de cotas e outros 99 foram aprovados na classificação geral. ${ }^{39} \mathrm{~A}$ não-ocupação integral da cota para negros, porém, está longe de representar um resultado negativo. Voltando ao exemplo anterior, se 11 das vagas reservadas para negros no curso de Medicina não foram preenchidas, não é possível desconsiderar que "há cerca de 15 anos não havia a entrada de um estudante negro" no curso (Notícias da UFPR, no 25, jun. 2005, p. 9).

Ao mesmo tempo em que sobraram vagas, um número expressivo de candidatos aprovados pelo sistema de cotas para negros - 127, de um total de 573 - teve seu registro acadêmico indeferido pela comissão responsável pela análise, supostamente objetiva, da "autodeclaração de grupo racial". Desses, 108 apresentaram recurso. Dois deles tinham problemas de documentação que foram rapidamente resolvidos. Os demais foram convocados para uma entrevista com a comissão. Um dos candidatos cancelou seu processo antes da realização da entrevista e outros dois não compareceram. Dentre os entrevistados, 70 foram aprovados pela comissão, "pois atendiam ao ponto do edital sobre apresentar 
fenótipo da raça negra". Os 33 restantes não puderam se matricular (Notícias da UFPR, no 29, out. 2005, p. 7).

O episódio foi amplamente divulgado pelos meios de comunicação locais, embora não tenha alcançado repercussão nacional. O jornal $G a-$ zeta do Povo entrevistou estudantes que esperavam para ser avaliados pela comissão. Diz a reportagem:

A história mais comum ouvida dos alunos envolvia miscigenação. Quase todos os estudantes alegavam ter pai branco e mãe negra, ou vice-versa. Outros diziam que tinham avós negros e citavam até ex-escravos na família. Quase nenhum se declarava preto, mas todos se diziam pardos e mostravam fotos de família ou documentos em que eram registrados como pardos para comprovar o que diziam. (Galindo, 2005b)

Enquanto isso, a exemplo do que também ocorreu em outras universidades, multiplicavam-se os processos judiciais contra o sistema de cotas. Na maior parte dos casos, candidatos que não foram aprovados na concorrência geral pleiteavam o direito à matrícula, argumentando que as médias obtidas nas provas teriam sido suficientes para garantir sua aprovação caso não houvessem cotas. Alguns deles chegaram a obter liminares garantindo o ingresso na universidade, mas a tendência predominante entre os juízes foi favorável à UFPR. De acordo com a imprensa, também candidatos às cotas que tiveram sua matrícula indeferida pela comissão teriam ingressado na justiça (Galindo, 2005b). Seja como for, já se sabe que o número de candidatos inscritos na cota para

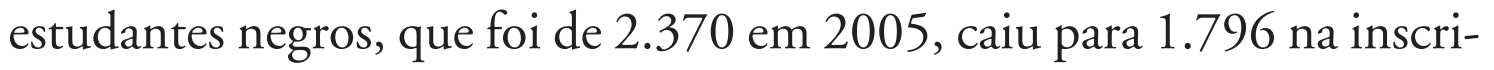
ção para o vestibular de 2006 (Nery \& Poniwass, 2005). 


\section{Notas}

1 Uma primeira versão deste trabalho foi apresentada no seminário temático "Formação de Estado e construção da nação: perspectivas sociogenéticas e antropológicas", coordenado por Antônio Carlos Souza Lima, Piero de Camargo Leirner e Gilberto Hochman no XXVIII Encontro Anual da Associação Brasileira de PósGraduação em Ciências Sociais (Anpocs), em outubro de 2004. Agradeço aos coordenadores e participantes - em particular Adriana Vianna e Carlos Valle, debatedores da sessão - pelos comentários e sugestões. Agradeço também aos pareceristas anônimos da Revista de Antropologia.

2 Estudos Avançados, vol. 18(50), 2004, com artigos de Octávio Ianni, Sérgio D. J. Pena e Maria Cátira Bortolini, Fátima Oliveira, Fúlvia Rosemberg, Yvonne Maggie e Peter Fry, Luís Roberto Cardoso de Oliveira, Waldir Quadros e Rubens de C. F. Adorno, Augusta Thereza de Alvarenga e Maria da Penha Vasconcellos, além de uma entrevista com o antropólogo Kabengele Munanga.

3 Horizontes Antropológicos, vol. 11(23), jan.-jun. 2005. Tendo como referência o artigo "Política de cotas raciais, os 'olhos da sociedade' e os usos da antropologia: o caso do vestibular da Universidade de Brasília (UnB)", de Marcos Chor Maio e Ricardo Ventura Santos, participaram do debate 18 pesquisadores das áreas de antropologia social, sociologia, história e genética: Antônio Sérgio Alfredo Guimarães, Bernardo Lewgoy, Célia Maria Marinho de Azevedo, Francisco M. Salzano, Gustavo Lins Ribeiro, José Carlos dos Anjos, José Jorge de Carvalho, Lilia Schwarcz, Livio Sansone, Luiz Fernando Dias Duarte, Márcia Lima, Maria Cátira Bortolini, Maria Rosário G. de Carvalho, Mariza Corrêa, Peter Fry, Rita Laura Segato, Sérgio D. J. Pena e Yvonne Maggie.

4 Além da procuradora-geral da UFPR, Dora Lúcia de Lima Bertúlio, compunham a comissão designada pela Portaria 822, de 8/8/2002, os professores Nizan Pereira de Almeida, Paulo Vinicius Baptista da Silva e Pedro Rodolfo Bodê de Moraes. Um ano e meio depois, outra portaria acrescentou mais três nomes à comissão: a professora Wanirley Pedroso Guelfi e os estudantes Evandro Charles Piza Duarte (pós-graduação) e Emanuel Ted Leem (graduação).

5 Programa destinado ao preenchimento das vagas decorrentes da evasão de alunos durante os cursos de graduação, cujos mecanismos de implantação ainda hoje suscitam críticas. 
6 Aprovada pelo Conselho de Ensino, Pesquisa e Extensão da UnB em 6/6/2003, a proposta entrou em vigor a partir do vestibular de junho de 2004.

7 O procedimento de fotografar os candidatos para fins de homologação das inscrições, objeto de vigorosa polêmica, não constava do projeto original (Carvalho \& Segato, 2002). Sobre as modificaçôes introduzidas durante o processo de implementação do sistema de cotas, ver Carvalho (2005) e Segato (2005).

8 Como assinala Yvonne Maggie, tal princípio estava presente desde a primeira lei estadual sobre cotas no Rio de Janeiro. No formulário de inscrição ao vestibular da Uerj de 2003, o candidato deveria responder à seguinte questão: "De acordo com o decreto $n^{\circ} 30.766$, de 4/3/2002, declaro, sob penas da lei, identificar-me como negro ou pardo: ( ) S-Sim / ( ) N-Não" (Maggie, 2005).

9 Além das três páginas da proposta do Plano de Metas de Inclusão Racial e Social, o processo $n^{\circ}$ 14.898/04-12 continha diversos anexos com informações sobre o perfil socioeconômico dos candidatos e calouros da UFPR (com ênfase na comparação entre brancos e negros), dados do IBGE sobre a população do Sul do Brasil por grupo de cor, recortes de jornais e textos acadêmicos enfocando a desigualdade racial no Brasil, além de cópias da proposta de reserva de vagas da UnB e da resolução que havia estabelecido cotas para negros na Universidade do Estado da Bahia em 2002. No total, o volume ultrapassava 300 páginas.

10 O relator justificava sua posição afirmando: "Por um lado, já existe legislação maior que dispõe sobre a utilização de documentos falsos ou fraudulentos. Assim, se algum candidato às cotas para estudantes de escola pública apresentar documentação falsa, sua inscrição fica, automaticamente, anulada. (...) Por outro lado, não vejo como poderia se considerar falsa ou fraudulenta uma autodeclaração, no caso dos candidatos às cotas para estudantes negros" (processo no14.898/04-12, parecer do relator).

11 Ao dispor sobre o Programa Nacional de Direitos Humanos (PNDH), o decreto no 4.229, editado em 13/5/2002, incluiu entre as Propostas de Açôes Governamentais do Anexo I: (...) "191 - Adotar, no âmbito da União, e estimular a adoção, pelos estados e municípios, de medidas de caráter compensatório que visem à eliminação da discriminação racial e à promoção da igualdade de oportunidades, tais como: ampliação do acesso dos afro-descendentes às universidades públicas (...) de forma proporcional a sua representação no conjunto da sociedade brasilei- 
Ciméa Barbato Bevilaqua. Entre o previsível e o contingente...

ra". Chamo atenção para a substituição da categoria "negros", adotada em 1996, por "afro-descendentes".

12 A título de comparação, a sessão anterior do Conselho Universitário, na qual foi apresentado o relatório dos dois primeiros anos da gestão 2002-2006, contou com a presença de 33 conselheiros titulares e três suplentes, além do reitor e da vice-reitora.

13 Optei não usar nomes próprios para evitar constrangimentos às pessoas mencionadas, ainda que esse recurso nunca seja inteiramente eficaz (cf. Bevilaqua, 2003). Utilizo a seqüência das letras do alfabeto para designar os conselheiros conforme a ordem de sua aparição no texto, permitindo assim que o leitor identifique a referência àquela pessoa em momentos posteriores. As letras entre parênteses indicam o modo de pertencimento ao Coun: $\mathrm{CD}=$ conselheiro diretor ou vice-diretor de setor; $\mathbf{C P}=$ professor, independentemente se representante de setor acadêmico ou classe da carreira docente; $\mathrm{CT}$ = técnico-administrativo; $\mathrm{CE}=$ estudante; $\mathrm{CCP}=$ representante da comunidade (patronal); e CCT = representante da comunidade (trabalhadores).

14 Artigo $14\left(\$ 6^{\circ}\right)$ do Regimento do Cepe e artigo $15\left(\$ 6^{\circ}\right)$ do Regimento do Coplad. Ambos, aliás, são praticamente idênticos.

15 O texto é idêntico nos dois documentos, mudando apenas o número do artigo correspondente nos regimentos do Coplad (Art. 10, $\$ 3^{\circ}$ ) e do Cepe (Artigo 9o, $\$ 4^{\circ}$ ).

16 Ao analisar a tramitação de proposiçōes no Congresso Nacional, Luiz Eduardo Lacerda de Abreu (1999) chama a atenção para os diferentes usos que o regimento pode ter e demonstra que seria inadequado eleger um uso particular - "o regimento entendido como norma” - como uso canônico. Em suas linhas gerais, penso que o argumento também é aplicável ao(s) uso(s) do regimento no contexto aqui discutido.

17 Artigo 14 (parágrafos $1^{\circ}$ e $2^{\circ}$ ) do Regimento Geral; artigo 14 ( $\$ 5^{\circ}$ ) do Regimento do Cepe; e artigo $15\left(\$ 5^{\circ}\right)$ do Regimento do Coplad.

18 Como observa Abreu (1999), classificar os argumentos como "técnicos" ou "políticos" é tão-somente um recurso analítico, já que um argumento aparentemente técnico pode ter uso político e vice-versa.

19 Aqueles a quem me refiro como a "linha de frente" do Coun não possuem necessariamente uma orientação comum. Embora isso possa ocorrer em alguns momentos, a "linha de frente" é também responsável pelas polarizaçooes mais evidentes durante os debates. A expressão aqui proposta é parcialmente inspirada pela análi- 
se de John Comerford sobre reuniōes de organizações camponesas. O autor chama de "'equipe de frente' o conjunto de pessoas que fala mais vezes e mais longamente nos momentos de discussão, a ponto de se destacar, e as demais, que basicamente assistem às falas dessas primeiras, de 'público'” (Comerford, 2002, p. 157).

20 Recebido com certo constrangimento no Conselho Universitário, esse raciocínio tem sido recorrente na discussão sobre cotas em contextos não-acadêmicos. Maggie e Fry (2004) reproduzem, por exemplo, diversas cartas de leitores ao jornal $O$ Glo$b o$, cujo fundo comum é a rejeição das cotas como forma de institucionalização do "apartheid brasileiro" ou de criação de "ressentimentos raciais".

21 Estavam presentes os 11 diretores de setores acadêmicos (nove titulares e dois vices em exercício).

22 A esse respeito, Maggie e Fry observam: "Na Constituição de 1988, as palavras 'raça' e 'racismo' aparecem três vezes, cada uma delas no sentido de repudiar 'raça' como critério de distinção" (2004, p. 67).

23 O número de candidatos aprovados na primeira fase dependeria de um fator de multiplicação baseado na relação candidato/vaga, variando de três a seis vezes o número de vagas disponíveis.

24 "Além disso, é importante destacar que a idéia de que os exames vestibulares selecionam os melhores candidatos para as carreiras da Universidade também não passa de um mito. O vestibular 'olha para trás' e - talvez - seleciona dentre os candidatos os que melhor se saíram em provas baseadas nos conteúdos do ensino médio. Na medida em que não há integração consistente entre os níveis de ensino, a suposição de que o melhor estudante no ensino médio será também o melhor estudante no ensino superior não passa de uma suposição" (processo $\mathrm{n}^{\circ} 14.898 / 04-12$, parecer do relator).

25 As votações são sempre abertas no Coun, exceto nas decisões a respeito de recursos. Cada conselheiro recebe um cartão impresso, escolhendo ao votar a face com o "sim" (isto é, a favor do parecer em discussão) ou com o "não" (a favor da proposta contrária).

26 A resolução no 196/2002 do Conselho Universitário da Uneb, que "estabelece e aprova quotas para população afro-descendente", dispõe, no parágrafo único de seu artigo 10: "Serão considerados afro-descendentes, para os efeitos desta Resolução, os candidatos que se enquadrarem como pretos ou pardos, ou denominação equivalente, conforme classificação adotada pelo Instituto Brasileiro de Geografia 
e Estatística - IBGE". Remeto o leitor à crítica ao uso da categoria "afro-descendente" feita por Sansone (2005) e Segato (2005), bem como às consideraçōes de Maio e Santos (2005b) nesse debate. Ver também Munanga (2004).

27 Desconsidero nesse momento as alterações introduzidas durante o processo de implementação do vestibular com cotas na UnB, com o uso de fotografias como forma de controle das inscrições.

28 Conforme o texto da comissão responsável pelo Plano de Metas, item III.6: "Os candidatos ao programa que fizerem declaração falsa ou fraudulenta serão desligados do programa perdendo o direito à vaga, bem como a sua participação no certame, sendo declarados excluídos do respectivo Processo Seletivo ao ingresso nos Cursos de Graduação da UFPR, além da responsabilidade civil e penal”.

29 Posteriormente, uma exceção foi estabelecida nas disposições transitórias: "Art. 11 - Nos Processos Seletivos do ano de 2005 poderão candidatar-se às vagas previstas no art. $2^{\circ}$ desta Resolução estudantes que tenham cursado até 01 (um) ano em escolas particulares".

30 Antes da ordem do dia, o conselheiro $\mathrm{R}(\mathrm{CP})$ pediu providências para a retificação de notícia publicada no final de semana pela Gazeta do Povo a respeito da votação da sexta-feira. De acordo com o jornal, a política de cotas havia sido aprovada por 21 votos a 19 [placar que se referia ao "escalonamento"], o que sugeria uma indesejável divisão do Conselho Universitário em matéria de tal relevância. Assim como as seguidas entrevistas concedidas pelo reitor, a manifestação do conselheiro era mais um indício de que a repercussão pública era um ingrediente fundamental nas decisóes sobre as políticas afirmativas.

31 Sobre o primeiro vestibular específico para estudantes indígenas na UFPR, ver Bevilaqua (2004).

32 Resolução no 196/2002 do Conselho Universitário, artigo 3o parágrafos $1^{\circ}$ e $2^{\circ}$.

33 Tomo de empréstimo aqui a síntese formulada por Márnio Teixeira-Pinto (1993) da concepção de sacrifício presente nos principais ensaios de Mauss sobre o tema (1981[1899]; 1968[1906]).

34 Em si mesmas, uma ou outra dessas concepções não poderia ser tomada como necessariamente superior. Por esse aspecto, Hermano Vianna aponta a "associação enganosa e quase automática, feita por setores hoje dominantes do movimento anti-racista, de mestiçagem com o mito de democracia racial". Ainda segundo o autor, deixa-se assim de considerar o potencial da mestiçagem como "uma das ar- 
mas mais poderosas para serem usadas no combate anti-racista, no Brasil ou fora do Brasil" (Vianna, 2004, p. 6).

35 Abreu (1999) propõe justamente definir a política como a articulação complexa entre ritual e jogo.

36 A ação foi considerada nula por ter sido proposta em Guarapuava, e não em Curitiba, sede da UFPR (Galindo, 2005a).

37 Só seria possível ter acesso a "um relatório básico para divulgação, organizado por curso, em ordem alfabética, contendo os nomes dos candidatos classificados até o limite de vagas do curso, sem menção de classificação ou de opção para as vagas de inclusão racial e social da UFPR" (art. 63, \$ único, do Edital no 001/2004 do Núcleo de Concursos, em conformidade com o artigo $5^{\circ}$ da resolução no 56/04 CEPE, de 4/6/2004).

$38 \mathrm{O}$ trecho por mim destacado indica critérios suplementares aos que haviam sido definidos pelo Conselho Universitário (art. $1^{\circ}$ da resolução no 37/04-Coun, que estabelece o Plano de Metas de Inclusão Racial e Social na UFPR, reproduzido anteriormente).

39 Dados fornecidos pelo Núcleo de Concursos da UFPR, publicados pelo jornal Gazeta do Povo (Campos, 2005).

\section{Bibliografia}

ABREU, L. E. L.

Os labirintos do Minotauro - troca, política e linguagem, Brasília, tese de doutorado, Universidade de Brasília, Departamento de Antropologia.

BEVILAQUA, C.

2003 "Etnografia do Estado: questôes metodológicas e éticas", Campos, Curitiba, PPGAS/UFPR, vol. 3: 51-64.

2004 "O primeiro vestibular indígena na UFPR", Campos, Curitiba, PPGAS/UFPR, vol. 5(2).

CAMPOS, M. A.

2005 "Sobrou cota na UFPR", Gazeta do Povo, Curitiba, 13/1/2005, p. 3. 
CARVALHO, José Jorge de.

2005 "Usos e abusos da antropologia em um contexto de tensão racial: o caso das cotas para negros na UnB”, Horizontes Antropológicos, Porto Alegre, UFRGS, vol. 11(23): 237-46.

CARVALHO, J. J. \& SEGATO, R. L.

2002 "Plano de metas para a integração social, étnica e racial da Universidade de Brasília” (documento consultado no processo no 14.898/04-12-UFPR).

COMERFORD, J.

2002 "Reunióes camponesas, sociabilidade e lutas simbólicas", in PEIRANO, M. (org.), O dito e o feito: ensaios de antropologia dos rituais, Rio de Janeiro, Relume-Dumará, pp. 149-68.

DA MATTA, R.

1979 Carnavais, malandros e heróis: para uma sociologia do dilema brasileiro, Rio de Janeiro, Guanabara.

DUMONT, L.

1992[1966] Homo hierarchicus: o sistema das castas e suas implicaçôes, São Paulo, Edusp.

GALINDO, R. W.

2005a "Ação pública contra cotas é nula", Gazeta do Povo, Curitiba, 18/2, p. 10.

2005b "Alunos barrados em sistema de cotas ameaçam ir à Justiça", Gazeta do Povo, Curitiba, 19/2, p. 3.

LIMA, M.

2005

"Ser negro no Brasil: do ônus ao bônus?", Horizontes Antropológicos, Porto Alegre, UFRGS, vol. 11(23): 258-61.

MAGGIE, Y.

2005

"Políticas de cotas e o vestibular da UnB ou a marca que cria sociedades divididas”, Horizontes Antropológicos, Porto Alegre, UFRGS, vol. 11(23): 286-91. 
MAGGIE, Y. \& FRY, P.

2004 "A reserva de vagas para negros nas universidades brasileiras", Estudos Avançados, São Paulo, vol. 18(50): 67-80.

MAIO, M. C. \& SANTOS, R. V.

2005a "Política de cotas raciais, os "olhos da sociedade" e os usos da antropologia: o caso do vestibular da Universidade de Brasília (UnB)", Horizontes Antropológicos, Porto Alegre, UFRGS, vol. 11(23): 181-214.

2005 b "As cotas raciais nos horizontes da antropologia: tréplica a dezoito comentaristas", Horizontes Antropológicos, Porto Alegre, UFRGS, vol. 11(23): 292-308.

MAUSS, M.

1968[1906] "Introduction à l'analyse de quelques phénomènes religieux", in Oeuvres 1. Les Fonctions Sociales du Sacré, Paris, Editions de Minuit.

MAUSS, M. \& HUBERT, $\mathrm{H}$.

1981[1899] "Ensaio sobre a natureza e a função do sacrifício", in MAUSS, M., Ensaios de Sociologia, São Paulo, Perspectiva, pp. 141-227.

MUNANGA, K.

2004 "A difícil tarefa de definir quem é negro no Brasil" (entrevista), Estudos Avançados, São Paulo, vol. 18(50).

NERY, A. C. \& PONIWASS, L.

2005 "Cai o número de candidatos cotistas no vestibular da Federal", Gazeta do Povo, Curitiba, 20/9, p. 3.

PEIRANO, M. 2002

"Prefácio. Rituais como estratégia analítica e abordagem etnográfica", in PEIRANO, M. (org.), O Dito e o Feito - ensaios de antropologia dos rituais, Rio de Janeiro, Relume-Dumará, p. 7-14.

SAHLINS, M.

1990[1985] Ilhas de História, Rio de Janeiro, Jorge Zahar. 
SANSONE, L. 2005

"O bebê e a água do banho - a ação afirmativa continua importante, não obstante os erros da UnB!", Horizontes Antropológicos, Porto Alegre, UFRGS, vol. 11(23): 251-54.

SEGATO, R. L. 2005

"Em memória de tempos melhores: os antropólogos e a luta pelo direito", Horizontes Antropológicos, Porto Alegre, UFRGS, vol. 11(23): 273-82.

TEIXEIRA-PINTO, $\mathrm{M}$.

1993 "Marcel Mauss: o sacrifício e a dádiva", in PAZ, F. (org.), As Aventuras do Pensamento, Curitiba, Editora da UFPR.

UNIVERSIDADE DO ESTADO DA BAHIA - Conselho Universitário

2002 Resolução no 196/2002 (documento consultado no Processo no 14.898/0412-UFPR).

UNIVERSIDADE FEDERAL DO PARANÁ.

2003 "Anteprojeto de Plano de Metas de Inclusão Racial e Social na UFPR".

2004a Processo no 14.898/04-12 - Conselho Universitário - Plano de Metas de Inclusão Racial e Social na UFPR.

2004b Edital no 001/2004, Núcleo de Concursos.

VIANNA, $\mathrm{H}$.

2004 "Mestiçagem fora de lugar", Folha de S.Paulo, Caderno Mais!, 27/4, p. 4-6.

DOCUMENTOS CONSULTADOS EM VERSÃO ELETRÔNICA, DISPONÍVEIS EM <WWW.UFPR.BR/SOC>:

Regimento Geral da Universidade Federal do Paraná

Regimento do Conselho Universitário da UFPR

Regimento do Conselho de Ensino, Pesquisa e Extensão da UFPR

Regimento do Conselho de Planejamento e Administração da UFPR

Resolução no 37/04- Coun/UFPR - Estabelece e aprova Plano de Metas de Inclusão Racial e Social na Universidade Federal do Paraná.

Resolução no 56/04- CEPE/UFPR - Altera artigos da Resolução no 85/03-CEPE que fixa normas complementares relativas ao Processo Seletivo ao ingresso nos Cursos de Graduação a partir do ano de 2005 e dá outras providências. 
Revista de Antropologia, São Paulo, USP, 2005, v. 48 no 1.

\begin{abstract}
This article presents an ethonographic account of the process of deliberation about affirmative actions at Universidade Federal do Paraná. The empirical approach of this controversial issue intends to bring new elements to the debate concerning the adoption of affirmative actions by brazilian public universities. At the same time, effort is made to identify the main principles underlying the establishment of institutional norms in that context. The analysis of ethnographic data suggests connections between the deliberation about affirmative actions and the logic of sacrifice as described by Marcel Mauss.
\end{abstract}

KEY-WORDS: public policy, affirmative action, universities.

Aceito em setembro de 2005. 